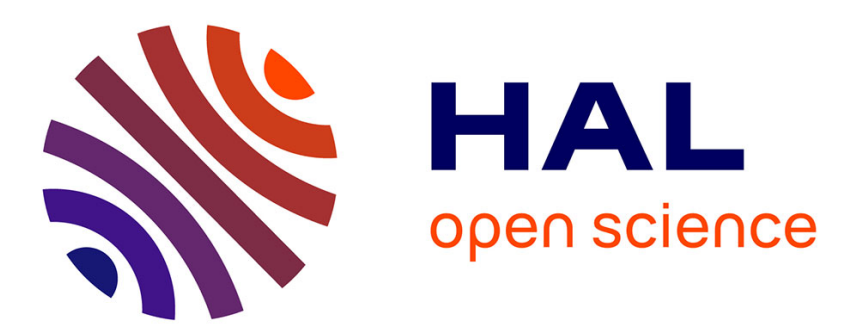

\title{
The 'terril' effect: coal mine spoil tips select for collembolan functional traits in post-mining landscapes of northern France
}

Benoît Vanhee, Sandrine Salmon, Cédric Devigne, Alain Leprêtre, Louis Deharveng, Jean-François Ponge

\section{To cite this version:}

Benoît Vanhee, Sandrine Salmon, Cédric Devigne, Alain Leprêtre, Louis Deharveng, et al.. The 'terril' effect: coal mine spoil tips select for collembolan functional traits in post-mining landscapes of northern France. Applied Soil Ecology, 2017, 121, pp.90-101. 10.1016/j.apsoil.2017.09.027 . hal-01600784

\section{HAL Id: hal-01600784 https://hal.science/hal-01600784}

Submitted on 2 Oct 2017

HAL is a multi-disciplinary open access archive for the deposit and dissemination of scientific research documents, whether they are published or not. The documents may come from teaching and research institutions in France or abroad, or from public or private research centers.
L'archive ouverte pluridisciplinaire HAL, est destinée au dépôt et à la diffusion de documents scientifiques de niveau recherche, publiés ou non, émanant des établissements d'enseignement et de recherche français ou étrangers, des laboratoires publics ou privés. 
1 The 'terril' effect: coal mine spoil tips select for collembolan functional traits

2 in post-mining landscapes of northern France

3 Benoît Vanhee $^{\mathrm{a}}$, Sandrine Salmon ${ }^{\mathrm{b}}$, Cédric Devigne $^{\mathrm{a}, \mathrm{e}}$, Alain Leprêtre $^{\mathrm{c}}$, Louis Deharveng ${ }^{\mathrm{d}}$,

4 Jean-François Ponge ${ }^{b, *}$

5 a Faculté de Gestion, Economie \& Sciences, Laboratoire Ecosystèmes et Responsabilités Sociales,

6 Université Catholique de Lille, 56 rue du Port, 59016 Lille, Cedex, France

7 b Muséum National d'Histoire Naturelle, CNRS UMR 7179, 4 avenue du Petit Château, 91800 Brunoy,

8 France

9 ' Université Lille 1, Laboratoire Génie Civil et Géo-Environnement, EA 4515, 59655 Villeneuve d'Ascq,

10 France

${ }^{\mathrm{d}}$ Muséum National d'Histoire Naturelle, CNRS UMR 7205, 55 rue Buffon, 75005 Paris, France

${ }^{\mathrm{e}}$ UDSL, Forensic Taphonomy Unit, EA 7367, F-59000 Lille, France

We sampled collembolan communities in 11 coal mine spoil tips (locally called 'terrils') from the

North of France, and their surroundings, in various stages of vegetation development (bare soil, herb,

shrub and tree vegetation). We wondered whether species, functional trait (Community Weighted

Mean trait or CWM) composition and trait diversity (Rao's quadratic entropy) responded to the and which of these three sets was the best indicator of soil and vegetation effects, taking into

\footnotetext{
* Corresponding author.

E-mail address: ponge@mnhn.fr (Jean-François Ponge)
} 
1 history and surrounding environment). We showed that species, but not traits, were strongly

2 influenced by site effects, while traits were influenced by both 'terril' and successional effects to a

3 significant extent, making traits more robust than species when trying to discern patterns of community response to soil and vegetation changes. Functional diversity did not show any significant multi-trait response to either 'terril' or successional effects, but several functional traits showed an increase in diversity with succession. The overall response of trait diversity was intermediate between species and trait responses. The 'terril' effect was mainly mediated by a coarser soil texture

8 (51\% coarse sand compared to $14 \%$ in the surrounding environment) which, combined with harsher

9 microclimate conditions, stems in a better representation of functional traits linked to subterranean life, such as shorter body length and increased representation of parthenogenesis. Successional

11 effects (in particular the increase in diversity shown by several functional traits varying with vertical

12 distribution) were mediated by the increasing development of organic horizons but other factors like 13 microclimate were seemingly involved, too. More generally this study showed that shift to 14 subterranean life was an adapted response of collembolan communities to harshness of the 15 environment and that vertically stratified ecosystems allow a more complete expression of their 16 functional diversity.

17 Keywords: coal mine spoil tips; Hauts de France; collembolan communities; functional traits; functional diversity; vegetation succession 


\section{Introduction}

Environmental filtering has been considered as a prominent source of variation of plant and animal communities at a level intermediate between regional species pools and species interactions (Rajaniemi et al., 2006). Coal mine spoil tips are thought to play the role of environmental filters for regional species pools (Molyneux, 1963; Kirmer et al., 2008), as could also be observed for instance in the colonisation of glacier moraines (Ingimarsdóttir et al., 2012). The need to adapt to such environments, known for their harsh microclimate and soil conditions and strong seasonal contrasts (Whitlock et al., 2015), can be expected to select for functional traits (sensu Pey et al., 2014) which might differ to a great extent from those of the surrounding woodland, agricultural or urban land (Frouz et al., 2013; Tischew et al., 2014). Vegetation succession, whether natural (primary succession) or under landscaping activities, superimposes changes in soil and microclimate which may impact in turn the composition of communities (Alday et al., 2011; Piekarska-Stachowiak et al., 2014; Markowicz et al., 2015). Thus coal mine soil tips, characterized by both strong selection pressure and strong heterogeneity (Whitlock et al., 2015), could be considered as good models for studying at community level the response of functional traits to environmental forcing (PiekarskaStachowiak et al., 2014).

Colliery waste heaps (also called coal mine spoil tips) are in high contrast with the flat surrounding agricultural or urban environment (Molyneux, 1963; Lemoine, 2012). Although their shape may vary according to present or past usages they generally look like conical hills made of waste deposits (more generally shale and/or sandstone) extracted from the subsoil while tunnelling it for coal extraction. Their height, generally between 50 and $100 \mathrm{~m}$, may exceptionally reach $200 \mathrm{~m}$ or more, with unstable slopes as steep as $100 \%$. Steep slope, darkness and coarse texture of extracted rock debris make the microclimate of coal mine spoil tips warmer and drier than the surrounding environment, as attested by the thermophilic nature of spontaneous vegetation, with strong analogies with coastal dune environments (Petit, 1980; Lemoine, 2012). Subterranean 
spontaneous and self-sustained combustion often occurs by places, because of the presence of coal remains in admixture with other deposits (Bell et al., 2001). After abandonment soil develops in the course of time, together with plant succession from pioneer mosses and lichens to woody plants (Down, 1973). The encroachment of natural vegetation is often artificially hasted by sowing grasses and planting trees, for recreation purposes and to prevent erosion.

Collembola are among the most abundant soil animal groups (Rusek, 1998) and their functional importance has been acknowledged from their involvement in bacterial- and fungal-based soil food webs (Filser, 2002; Chahartaghi et al., 2005; Murray et al., 2009), the translocation of litter carbon to soil (Chamberlain et al., 2006), the control of fungal pathogens (Mitschunas et al., 2006) and the dispersal of microbial and plant diaspores (Cronberg et al., 2006), giving them the status of "ecosystem engineers" (Bispo et al., 2009). Species traits are known to vary vertically according to the stratification of ecosystems (Prinzing and Woas, 2003; Rusek, 2007; Krab et al., 2010; Salmon et al., 2014) and horizontally according to land-use changes (Salmon and Ponge, 2012; Santorufo et al., 2015; Martins da Silva et al., 2016; Winck et al., 2017) and other environmental influences (Salmon et al., 2014). Soil collembolan communities have been already inventoried in coal mine spoil tips (Hutson, 1980; Moore and Luxton, 1986), as well as in other types of mining activities, such as reclaimed lignite strip-mining sites (Dunger et al., 2001, 2004; Dunger and Voigtländer, 2005), but nothing is known in terms of trait responses to environmental factors.

We needed to ascertain in the studied region to which extent collembolan communities of coal mine spoil tips differed from their surrounding environment (a contrast here collectively called 'terril' effect) and varied according to vegetation development. We hypothesized (Hypothesis $\mathrm{H} 1$ ) that trait modalities linked to subterranean life such as short appendages, absence of pigmentation and of sexual reproduction (Hopkin, 1997) were favourable to survival in warmer and drier environments, i.e. were increased in representation by the 'terril' effect, like in coastal dune and desert soils (Wallwork, 1972; Koehler et al., 1995), and were also favoured by the concomitant 
development of soil and vegetation, as observed when comparing 'open' and 'closed' areas (Salmon et al. 2014). The use of functional traits, which directly express the adaptation of species to a given environment (Bokhorst et al., 2012; Santorufo et al., 2015) was justified by the need to discern environmental drivers of community change, above variation due to spatial and historical patterns, here grouped under the 'site' effect. We also wanted to know whether the natural or artificial development of vegetation on abandoned coal tips (from bare soil to trees, passing by herbaceous and shrubby stages), known to increase the vertical stratification of the soil niche (Salmon et al., 2014), would increase in turn the functional diversity of collembolan communities (Hypothesis H2). If it is known that functional diversity increases with special richness in plant communities (Petchey and Gaston, 2002), and if it is known that collembolan species richness increases with stand development (Addison et al., 2003), nothing such is known as yet for functional diversity. At last we wonder whether species, traits and trait diversities had their own specificities when assessing environmental effects on collembolan communities. We hypothesized that functional traits, being directly influenced by environmental effects (Santorufo et al., 2015), are more robust than species to assess environmental effects at community level, and that trait diversity, being driven by processes in which both species and traits are involved (Mayfield et al., 2010), are intermediate in robustness (Hypothesis H3).

For this study we selected 11 'terrils' located in the North of France, the use of which declined progressively from 1960 on and was definitely abandoned in 1990 (Ladoucette, 2004).

\section{Material and methods}

\subsection{Study sites}

Nineteenth and $20^{\text {th }}$ centuries knew a dramatic expansion of industrial activities based on coal mining as the dominant source of energy (Hubbert, 1956). Coal mining activities ceased progressively in the second half of the $20^{\text {th }}$ century, leaving a flat landscape punctuated by coneshaped coal spoil tips (colliery spoil heaps), locally called 'terrils'. These artificial hills were later left 
untouched for most of them or reworked for recreational purposes (Lemoine, 2012). Given their richness in rare thermophilic plant and animal species these 'terrils' got a conservation status and were studied by universitary scientists (Petit, 1980, 1983; Godin, 2002). In 2012 the Nord Pas-deCalais Mining Basin has been included in its entirety in the UNESCO World Heritage List (UNESCO, 2012). A). They are representative of the western part of the Nord Pas-de-Calais Mining Basin. Coal mine spoils were mostly made of shale and sandstone deposits of varying texture, with a dominance of coarse sand in the 2-mm sieved fraction (Table 1). Their edification started in the first half of the $20^{\text {th }}$ century. The end of edification is difficult to establish rigorously, given that mining activities declined over ca. 30 years (1960-1990) with temporary recovery during the 70s, and some former conical spoil tips were partly exploited for various purposes after mining activities have ceased, stemming in truncated of flat appearance. Primary succession took place after abandonment, at a rate and a species composition highly influenced by the local species pool, as commonly observed in similar site conditions (Kirmer et al., 2008; Alday et al., 2011; Tischew et al., 2014). Three types of land use were considered to describe the surrounding environment: urban (included in the city), rural (included in an agricultural landscape) and woodland (Appendix A). Several stages of vegetation development, from bare soil to herbaceous then to shrub and to tree vegetation (mainly silver birch, Betula pendula Roth.) are still already visible today and were selected for sampling, when present (bare soil or woody vegetation can be lacking). Colonization by birch was more rapid and occurred over higher areas when this wind-dispersed tree species was present in the immediate environment (woodland environment). Some 'terrils' were revegetated (mainly with silver birch) and landscaped for recreational purposes. Combinations of surrounding landscapes and successional stages result in various environmental conditions at local level. Sampling was done in order to reflect the variety of conditions found in the mining basin, taking also into account the immediate environment where bare soil, herb, shrub and tree vegetation (when present) were sampled for the sake of comparison. 
1

2

3

4

5

In total 81 sample points were selected, shared in 37 for spoil tips and 44 for the surrounding environment (Appendix E). Note that sampling reflected the fact that the distribution of the four successional stages was naturally unbalanced between spoil tips and their environment, impeding any orthogonal treatment of the data.

\subsection{Sampling and extraction}

Sampling took place at each sampling point by forcing a cylindrical core $(8 \mathrm{~cm}$ diameter, $11 \mathrm{~cm}$ depth) in the soil. This operation was duplicated in order to obtain ca. one cubic decimetre of soil, which was carried in polythene bags back to the laboratory. Extraction was achieved in 7 days in Berlese-type funnels, below which soil animals escaping drying soil samples were collected in a mixture of ethyl alcohol (70 \%) and ethylene glycol (30\%). Collembola were mounted in lactic acid then were counted and identified using various keys (Gisin, 1960; Bretfeld, 1999; Potapow, 2001; Thibaud et al., 2004; Hopkin, 2007; Dunger and Schlitt, 2011; Jordana, 2012).

\subsection{Soil features}

At each sampling point two additional soil samples were taken then sent to soil analytical laboratory for measurement of pH (ISO, 2005), organic matter (ISO, 1995a), total nitrogen (ISO, 1995b), carbon/nitrogen ratio and particle size distribution (ISO, 2009). All analytical results are presented in Appendix E.

\subsection{Data collection and treatment}

Species functional traits were taken from the Coltrait database (Salmon et al., 2014) and were transformed in a small number of non-overlapping modalities, ranging from 2 to 4 depending on traits (Table 2, Appendix B). A small number of species (less than $10 \%$ ) could not be found in the database, for which original diagnoses were used to complete the table for the 107 species collected during the study. When building the Coltrait database species traits were directly measured on adults or taken from published diagnoses. We are aware that not taking into account within-species trait 
variation, in particular ontogenetic changes, could impact our results, as this has been demonstrated in vegetation studies when saplings and adult trees were confounded (Spasojevic et al., 2014). In our dataset only body length will be impacted by this simplification, because other traits (body shape and colour, eye number, presence of trichobothria, ocelli, and anal spines, relative lengths of appendages) do not change to a great extent along a springtail's life (Hopkin, 1997), or are relative to a whole springtail's life (reproduction mode).

In a first step we performed an indirect gradient analysis, here Principal Components Analysis (PCA), of species occurrences, using presence/absence in place of abundance and Spearman (rank) in place of Pearson (linear) as a measure of correlation between variables. This multivariate method has been already used to analyse binary data (Debinski and Brussard, 1994; Troia et al., 2012) and was judged better than correspondence analysis (a multivariate method adapted to count data) when searching for gradients (Kenkel, 2006). For this analysis we used only species present in more than two samples, letting 74 species as active variables. Explanatory variables (nine soil parameters as listed in Table 1 and Appendix E, spoil tip versus surrounding environment, the three kinds of surrounding environment, the four successional stages) were added as passive variables, using the same measure of distance (rank correlation coefficient) than active variables. Functional traits were also added as passive variables, affecting a score to each trait according to scaled modalities (Table 2, left column). For each trait the score varied from 1 (absence) to 2, 3 or 4, affecting an arbitrary number to each step of the corresponding scale. These values were averaged for each sample, after each species has been weighted by its relative abundance (Appendix E), thus giving the same trait value to all individuals belonging to the same species. This community assessment of trait values has been called Community Weighted Mean (CWM) trait by Garnier et al. (2004) and has been used for studying the response of soil animal communities to environmental change (Moretti and Legg, 2009; Bokhorst et al., 2012; Malmström, 2012). CWMs were calculated on the whole set of species, thus including those present in more than two samples. 


$$
Q=\sum_{i} \sum_{j} D_{i j} \times p_{i} \times p_{j}
$$

$p_{i}$ et $p_{j}$ are the relative frequencies of species $i$ et $j$, respectively

$$
D_{i j}=\left(A_{i}-A_{j}\right)^{2}
$$

$A_{i}$ and $A_{j}$ are the values of trait $\mathrm{A}$ for species $i$ et $j$, respectively 
rigorously equal to trait variance (Appendix $C$ ). We also showed that when traits have only two modalities (for instance presence versus absence) Rao's quadratic entropy (or trait variance) is a quadratic function of standardized CWM, passing by a maximum for a value of 0.5 (Appendix C). Rao's multi-trait functional diversity (Botta-Dukát, 2005; Schleuter et al., 2010) was calculated using the Euclidean distance between species (i.e. the sum of single-trait squared differences) as a measure of their dissimilarity (Champely and Chessel, 2002).

In a second step we tested whether soil features, species traits and trait diversity varied according to the 'terril' effect (spoil tip versus surrounding environment) and the successional stages (bare, herb, shrub, and tree). For that purpose we used Kruskal-Wallis rank tests followed by Dunn tests with Bonferroni adjustment for multiple comparisons among groups (Tables 1-3). Rank correlation coefficients between the first two components of PCA, soil variables, CWM values and trait diversities were also calculated (Appendix F).

In a third step we used Redundancy Analysis (RDA), a direct gradient multivariate method complementary to PCA (Van den Wollenberg, 1977), to test for site, the 'terril', succession, land use, and soil effects on species (presence/absence), functional traits (CWM-RDA, Kleyer et al., 2012) and multi-trait functional diversity (Rao's quadratic entropy). Tests were performed with Monte-Carlo simulation (500 permutations). Partial RDA was used to partial out several components of the whole effect ( $\varnothing$ kland, 1996) and combinations of partial and simple RDAs were used to address some specific questions, in particular whether site specificity may mask or not overall effects of soil and vegetation development. For this purpose we included or not some factors in the model, and fixed them (as co-variate or confounding factor) or not. As an example of reasoning we wanted to ask whether the 'terril' effect was mediated or no by soil effects when all other effects were discarded: for this purpose we performed two tests with site, successional stage, and surrounding land-use as fixed factors, one (1) with soil not included in the model and thus allowed to vary, and the other (2) with soil included in the model but fixed (testing for pure 'terril' effect because all other factors are 
1 fixed). If test (1) is significant while test (2) is not, it means that the 'terril' effect was mediated by

2 soil.

All calculations were done with $\mathrm{XLSTAT}^{\circledR}$ version 18.07 (Addinsoft ${ }^{\circledR}$, Paris, France).

\section{Results}

The first two principal components of PCA extract $13.2 \%$ of the total variation in species composition (6.8 and $6.4 \%$ for PC1 and PC2, respectively), a low value quite expected in indirect gradient analyses with a high number of active variables (74 species) and observations (81 samples). The projection of samples and species in the PC1-PC2 scatterplot shows a fairly good spread along both axes, without any visible horseshoe (curvilinear distortion) effect (Appendix D).

The projection of explanatory variables (Fig. 1) shows that PC1 mainly represents the 'terril' effect, as shown by ST, ST bare, ST herb, ST shrub and ST tree having positive scores, while ENV, ENV bare, ENV herb, ENV shrub have negative scores and ENV tree has a nil score. PC2 mainly represents the successional effect, with ST bare, ENV bare, ST herb and ENV herb having negative scores while ST tree, ENV tree and ENV shrub have positive scores. The only exception is ST shrub with weakly negative scores along PC2. Anyhow, whether in spoil tips or in their surrounding environment, early successional stages (bare, herb) have lower scores along PC2 than late successional stages (shrub, tree). The significance of PC1 and PC2 according to 'terril' and successional effects, respectively, has been verified by Kruskal-Wallis rank tests (Table 1$)$. The 'terril' effect is mainly displayed by PC1 $(\mathrm{P}<$ 0.0001) while PC2 mainly represents the successional effect $(P<0.0001)$, but some (although weaker) contrast between spoil tips and the surrounding environment is also represented by PC2 at a lower level of confidence $(P<0.01)$, while a contrast between successional stages is also represented by PC1 $(P<0.0001)$, as already suggested by Figure 1 . This indicates that both factors are not strictly independent, although a similar successional trend (involving the same species replacements) can be evidenced in spoil tips and in their surrounding environment. The projection of the variable 'Species richness' in the PC1-PC2 scatterplot shows that sample species richness is mainly correlated with 
PC2, thus with plant succession and associated changes in soil resources and habitats. It has been verified that species richness of the samples increases with plant succession, near doubling from 7.4 species in bare soil to 14 species under trees $(P<0.0001)$ but does not differ between spoil tips and their environment (11.5 and 12.3, respectively).

Some explanatory variables are projected far from the origin in the PC1-PC2 scatterplot, thereby indicating a strong correlation with the first two PCA components. This is the case of $\mathrm{pH}$, which exhibits a strong negative correlation with PC2 $\left(r_{s}=-0.42, P<0.001\right.$, Appendix F), and thus decreases with plant succession, but not with PC1 $\left(r_{s}=-0.072, P=0.52\right.$, Appendix F), and thus does not seem to differ between spoil tips and their surrounding environments. This has been verified by non-parametric tests (Table 1): pH decreases from 7.7 in bare soil to 6.2 under trees (1.5 unit less, i.e. 30 times less protons), but does not vary between spoil tips (6.9) and their surrounding environment (6.8). Figure 1 and Table 1 show that the soil nitrogen content near doubles along the successional gradient (from 2.5 to $4.5 \%$ ) but only slightly decreases from spoil tips (3.6\%o) to surrounding environments (3.1\%o). Similar variations have been also observed in the organic matter content, with a doubling from 41 to $81 \%$ according to succession, and a 68 to $50 \%$ o decrease from spoil tip to environment. Nitrogen and organic matter contents are strongly and positively correlated $\left(r_{s}=0.77\right.$, $P<0.001$, Appendix F). The $\mathrm{C} / \mathrm{N}$ ratio does neither show 'terril' nor successional effect, indicating that the increase in nitrogen content is only due to the increase in organic matter, not to a change in organic matter quality. Among soil textural classes, PC1 shows a strong contrast between fine textural classes with strongly negative scores (clay, fine and coarse silt), and coarse sand with strongly positive scores, fine sand being in an intermediary position, with a slightly positive score. Non-parametric tests (Table 1$)$ show that, to the exception of fine sand, there is a high contrast $(\mathrm{P}<$ 0.0001 ) between spoil tips (with coarse texture) and their environment (with fine texture). Woodland, urban and rural land uses are projected far from the origin in the PC1-PC2 scatterplot (Fig. 1). This shows that they contribute to explain the species composition of collembolan communities, with a contrast between urban and woodland land uses along PC2, i.e. in the direction 
of plant succession, with agricultural land in an intermediary position. This suggests that the influence of land use is probably indirect, plant succession seemingly reaching sooner (and thus more often) the tree stage when spoil tips are inserted in a forested landscape. This has been verified by the examination of aerial photographs (data not shown). At last, the existence of a site effect is revealed by the spread of the different sites in the PC1-PC2 scatterplot (Fig. 1). However, it must be noticed that the spread of sites is not due only to their own respective characteristics, as detailed in Appendix A, but also and most probably only to the unbalanced distribution of vegetation types among them, resulting in unbalanced sampling of associated collembolan communities between bare, herb, shrub and tree successional stages. Overall results depicted in Figure 1 and Table 1 show that the species composition of collembolan communities responds to a variety of more or less correlated environmental factors ('terril' effect, plant succession, soil features, surrounding land use). They also suggest that soil and land use effects can be at least partly explained by 'terril' and successional effects.

Based on the interpretation of PC1 and PC2 as 'terril' and successional effects on collembolan communities, respectively, the projection of species functional traits in the PC1-PC2 scatterplot (Fig. 2) shows that most traits, to the exception of body colour and body shape which are projected not far from the origin, are influenced by one or the other factor or most often by both of them. Most pronounced variation along PC1 (as deduced from arrow lengths on Fig. 2) is decreasing body length, furcula and antenna relative lengths, decreasing presence of trichobothria and scales, decreasing ratio of sexual reproduction and decreasing eye number on one hand, increasing complexity of postantennal organs and increasing presence of anal spines and pseudocelli on the other hand. All CWM trait values, to the exception of body colour, are significantly correlated with PC1 (Appendix F). The association of these trends with the 'terril effect' (Table 2 ) has been verified for antenna length $(\mathrm{P}<$ 0.001), trichobothria $(P<0.001)$, body length $(P<0.01)$, post-antennal organ $(P<0.01)$, scales $(P<$ 0.01), reproduction type $(P<0.05)$, and furcula length $(P<0.05)$. Typically, according to our results 
Collembola living in spoil tips are smaller, with shorter jumping and sensorial appendages, without scales and trichobothria, with developed post-antennal organs, and parthenogenetic.

Most pronounced variation along PC2 was decreasing relative leg and furcula lengths, decreasing ratio of sexual reproduction and eye number, decreasing presence of trichobothria and scales, and increasing body length. The association of these traits with plant succession has been verified by Kruskal-Wallis test for reproduction type $(P<0.0001)$, eye number $(P<0.0001)$, leg length $(P<0.05)$, furcula length $(P<0.05)$ and trichobothria $(P<0.05)$. Only one discrepancy occurs between the association of functional traits with successional stages according to PCA (Fig. 2) and non-parametric tests (Table 2). It concerns antenna length, which is poorly associated with PC2 (Fig. 2, Appendix F) while it significantly decreases under trees (Table 2). Typically, according to our results Collembola living in open environments (in bare areas or under herbaceous vegetation) have a sexual reproduction, large eye spots, trichobothria and long furcula and legs, while those living in woody environments (under shrubs or trees) exhibit opposite trait modalities.

Figure 3 shows that trait diversity is influenced by factors represented by PC1 and PC2. The diversities of trichobothria and scale presence, body length, body shape, and eye number decrease along PC1 (see Appendix F for sign and significance of correlation coefficients). It has been verified (Table 3) that all these trait diversities decrease from the surrounding environment to spoil tips, with the highest level of significance $(P<0.0001)$ being displayed by trichobothria diversity. Typically, Collembola living in spoil tips exhibit a lower diversity for trichobothria, scales, body length, body shape and eye number. They are thus morphologically more similar than those living in the surrounding environment. However, some variation in trait diversity is displayed by PCA but not confirmed by non-parametric tests. This is the case for the increasing diversities along PC1 shown by anal spines, pseudocelli, and leg and furcula lengths (Fig. 3, Table 3).

The diversity of antennal length, body colour, reproduction type, anal spines, leg length, furcula length and pseudocelli increases, while that of body length decreases along PC2 (see 
Appendix F for sign and significance of correlation coefficients). The relationship with successional stage has been verified for antennal length, body colour, anal spines, furcula length, pseudocelli, and body length diversity (Table 3). Multi-trait functional diversity increases along PC2 $\left(r_{s}=0.30, P<0.01\right.$, Appendix F) but the relationship with successional stages is not significant (Table 3). With the exception of body size, it can be said that Collembola living in open environments of the study site are morphologically more similar than those living in woody environments.

It should be noted that Rao's trait diversity (= trait variance) is strongly related to standardized CWM (Appendix C). The two parabolic curves (Rao's trait diversity and trait variance) show that trait diversity increases from 0 when all species are similar, whether by the common presence or absence of a trait, to a maximum of 0.25 when CWM has a standardized value of 0.5 (all trait modalities equally distributed around the mean value).

Redundancy analysis (RDA) shows that combined site, 'terril', successional, land use and soil effects explain from 39 to $43 \%$ of total variation in species composition, CWM and trait diversity (Table 4, test 1). When site effects are discarded, these percentages fall to values from 16 to $25 \%$, trait diversity being most affected (Table 4, test 2). Pure site effects (all other factors fixed) represent 14 to $16 \%$ of total variation in species, CWM and trait diversity, without reaching significance level on CWM (Table 4, test 3), while shared site effects increase slightly from 16 to $19 \%$ of total variation, here too without reaching significance level on CWM (Table 4, test 4). Thus species composition is highly influenced by the site effect (whether pure or shared), trait diversity also, although to a lower extent, while CWM is not influenced at all.

We wanted to test whether site effects are at least partly mediated by the dominant land use surrounding the spoil tips. When allowing the land use to vary while all other factors are included and fixed, site effects (Table 4, test 5) are roughly the same as when land use is fixed (Table 4, test 3). Species strongly respond to the site effect, while CWMs do not, and trait diversities show an intermediate (although significant) response, whether land use is allowed to vary or not, pointing to 
a negligible influence of this factor on the site effect. However, we may ask whether the surrounding landscape can have a more direct influence on collembolan communities, i.e. is not just a surrogate of site effect. For that purpose we discarded the site effect from the model and fixed all factors to the exclusion of the land use effect (Table 4, test 6 ). Only species composition can be explained by this factor, and that highly significantly, despite the poor $4 \%$ of variance explained.

We wanted to test whether 'terril' and successional effects are mediated (or not) by the soil effect, since we showed that soil features vary according to the 'terril' effect (spoil tips have a coarser soil texture, Table 1) and to the successional stage (organic matter and nitrogen increase and $\mathrm{pH}$ decreases along succession, Table 1 ). When soil is not included in the model while site, successional and land use effects are included and fixed (Table 4, test 7), species and CWMs are significantly influenced by the 'terril' effect while trait diversity is not. When soil is fixed (Table 4, test 8) species and trait diversity are significantly influenced by the 'terril' effect while CWMs are not. Thus 'terril' effects on functional traits are seemingly mediated by soil, while species composition is affected by soil but also by other factors, and trait diversity is affected only (although to a much lower extent than species) by other factors than soil.

Contrary to the 'terril' effect, successional effects do not differ to a great extent when site, 'terril' and land use effects are fixed while soil is allowed to vary or not (Table 4, tests 9 and 10, respectively). Species, CWMs and trait diversities are all affected by successional effects, whether soil varies or not, pointing to other influences than soil physical-chemical properties as factors mediating successional effects.

At last, we wondered whether pure soil effects (all other potential effects discarded, including the soil-mediated 'terril' effect) can explain species, CWM and trait diversity effects. The corresponding model (Table 4, test 11) shows that species do not react at all to soil itself, while trait and trait diversities do, although at a low level of significance.

\section{Discussion}


4.1. Functional traits of collembolan communities differ according to 'terril' and successional effects, despite site-specific variation

Hypothesis $\mathrm{H} 1$ was fully verified: functional traits of collembolan communities differ according to 'terril' and successional effects, despite site-specific variation. We showed that functional traits are not influenced by the site effect, contrary to species composition. Widenfalk et al. (2015) pointed to the interest of traits, better than species, when comparing spatially distant sites sharing similar environmental conditions. Reasons advocated are that (i) species with similar ecological requirements share the same traits, thereby similar environments will harbour the same suites of traits (Lavorel and Garnier, 2002), and (ii) species are submitted to stochastic influences, such as species-specific source-sink dynamics (Hertzberg 1997; Kirmer et al., 2008; Ingimarsdóttir et al., 2012) and checkerboard distributions resulting from negative interactions (Widenfalk et al., 2016), which do not affect functional traits or affect them to a much lower extent than species (Mayfield et al., 2010).

\subsection{Functional traits and the 'terril' effect}

We showed that at community level, traits are affected by the 'terril' effect and that this effect is mediated by soil factors. Traits negatively affected by the 'terril effect' are body size, sexual reproduction, jumping appendages and sensorial organs, scales and trichobothria, indicating an adaptation to belowground life (eu-edaphic life-form) where space is limited for movements, including search for food (Auclerc et al., 2010) and sexual partners (Chahartaghi et al., 2006; Chernova et al., 2010), escape of predators (Salmon et al., 2005), and aggregation (Verhoef et al., 1977; Negri, 2004). Conversely, the development of compound post-antennal organs, the sensorial role of their vesicles has been deduced from anatomical investigations (Altner and Thies, 1976), is typical of soil-dwelling groups such as Tullbergiidae, Onychiuridae and many Hypogastruridae (Hopkin, 1997). Salmon et al. (2014) confirmed on a wide array of samples (926) recorded at European level that collembolan traits associated to deep soil are the absence of pigmentation, 
1 furcula, ocelli, trichobothria and scales, the presence of compound post-antennal organs and

2 pseudocelli, and the reduction of body size, legs and antenna, to the notable exception of some

3 common eu-edaphic species such as Isotomiella minor. In our dataset all these traits responded

4 similarly to the 'terril' effect, to the exception of body colour (Table 2). It is well-known that most

5 soil-dwelling springtails are depigmented, a trait often used to sort this functional group without resorting to species identification (Rusek, 2007). This discrepancy might indicate that either (i) body pigmentation, ensuring UV-protection (Leinaas, 2002), displays a high level of phylogenetic inertia and thus can be conserved even when unnecessary as already known from plant pigments (Lee, 2002), or (ii) trade-offs exist with other adaptive traits (Roff and Fairbairn, 2007). Both processes may result in pale colours shared with springtails living at or near the surface, such as for instance the epigeous pale-yellow Entomobrya lanuginosa (Ponge, 1993), and dark-coloured springtails having a wide vertical range distribution, such as the predatory Friesea truncata (Ponge, 1993, 2000). Similarly, pseudocelli, known as chemical defence organs in collembolan species which cannot escape predation by jumping (Usher and Balogun, 1966; Dettner et al., 1996), were not preferentially associated with spoil tips (Table 1). We cannot address more accurately these issues with our data, given that our sampling was not vertically stratified (Berg et al., 1998).

We showed that the soil of studied colliery spoil tips has a coarser texture, resulting in a better developed 'porosphere' (Vannier, 1987), and is in average richer in nitrogen and organic matter than the surrounding soil (Figure 1, Table 1), thus allocating space and nutrients to the animals which avoid the harsh conditions prevailing at the ground surface (Kent, 1982). The fact that trait modalities associated with belowground life (small size, reduced or absent sensorial and jumping organs, parthenogenesis) characterize spoil tips at community level (CWM) indicates that species living at or near the surface are only secondary components of spoil tip collembolan communities, whatever the soil is covered or not with vegetation. It should be noted that the adaptation to subterranean life is also accompanied by an increased tolerance to high carbon dioxide concentrations (Zinkler and Platthaus, 1996), a 'hard' trait (sensu Violle et al., 2007) probably of 
1

2

utmost importance in or near spontaneous combustion zones with burning charcoal remnants (Kent, 1982). It should also be highlighted that according to the QBS index (Parisi et al., 2005), the dominance of suites of traits associated with subterranean life indicates a good soil quality inasmuch as species richness remains at a 'normal' level in spoil tips (Table 1).

We may wonder why the 'harsh' environmental conditions of coal mine spoil tips do not favour traits associated with stress tolerance, such as those reported in alpine environments (Zettel, 2000) and following extreme temperature events (Van Dooremalen et al., 2013), with cold and heat hardiness being the privilege of dark-coloured, motile aboveground-living collembolan species. It must be argued that there exist two 'strategies' by which an animal can escape stressful conditions: either it must move to find rapidly a refuge at the ground surface (Ponge et al., 2006; Salmon and Ponge, 2012) or dip in the soil, using pore networks between mineral particles or earthworm galleries when present (Salmon et al., 2005). Given that environmental conditions prevailing in the soil are more stable than above it (Vannier, 1987; Van Dooremalen et al., 2013) soil is expected to constitute an efficient refuge for the more fragile species, provided (i) these species are adapted to subterranean life, i.e. harbour small size, reduced or absent sensorial and jumping organs, parthenogenesis, (ii) there is a well-developed porosphere (Vannier, 1987). In the absence of one or the other of these two conditions, only the first strategy (surface movement) will be feasible. This is the case in permanently or seasonally frozen or waterlogged soils (Chang et al., 2013), or when the soil is compact (Larsen et al., 2004).

\subsection{Functional traits and the successional effect}

We showed that at community level functional traits are affected by successional effects (the shift from bare soil to herbaceous then to shrub and finally to tree cover) but also that, contrary to the 'terril effect', factors other than soil are also in play. Traits which vary according to plant succession are eye number, leg and furcula length, and trichobothria, which all decrease in CWM value with vegetation development, and reproduction type (increased representation of 
parthenogenesis with succession). All these trends are related to the passage from open to close environments, with associated shifts in trait representation (Salmon and Ponge, 2012; Salmon et al., 2014; Santorufo et al., 2015; Martins da Silva et al., 2016), like in the abovementioned 'terril' effect. Both climate and soil are involved in the contrast between open and close environments, the effects of both factors on collembolan communities having been experimentally disentangled by transfers of soil blocks between forest and pasture (Heiniger et al., 2015). The buffering effect of woodland against wind, frost and aridity (Ashcroft et al., 2012) allows less mobile species (with short appendages and/or asexual reproduction) and more sensitive species (with a lower tolerance to desiccation) to find a refuge in forested environments (Chernova et al., 2010; Van Dooremalen et al., 2013). Changes in CWMs along successional seres have been the object of investigations by plant ecologists (Kahmen and Poschlod, 2004), coal mine spoil tips included (Piekarska-Stachowiak et al., 2014), and that from the seminal work by Garnier et al. (2004) who showed that species with contrasting characteristics (called 'biological markers') were replaced along successional trajectories.

4.4. Does the diversity of collembolan functional traits increase with the development of vegetation?

We showed that trait diversity increased with plant succession for a number of functional traits (Fig. 3, Table 3) but this effect was trait-specific, resulting in the absence of a statistically significant multi-trait trend. Thus our hypothesis $\mathrm{H} 2$ was only partially supported by our dataset. Traits the variety of which increased with the successional stage were body length, antenna and furcula length, pseudocelli number, anal spines, and body colour. It is worth to notice that body length did not respond to the successional stage when expressed as mean trait value (CWM) but did it when expressed as trait variety. Conversely, some traits the average value of which varied according to plant succession (reproduction type, eye number, leg length, trichobothria) did not vary in variety according to this factor. This suggests at first sight that discrepancies exist between CWM values and trait diversity values, which do not follow the same laws and are thus complementary in the search for assembly rules (Ricotta and Moretti, 2011). The increase in organic matter content 
1 from bare soil to tree cover (Table 1) and the concomitant increase in the number of soil horizons

2 within and underneath litter from early to late successional stages (Emmer and Sevink, 1994)

3 suggests that the number of potential niches for collembolan communities increases with plant

4

5 succession (Berg et al., 1998). This results in an increasing number of species per sample (Greenslade and Majer, 1993; Rusek, 2004), as verified in the present study (Table 1), but also in an increase in functional trait diversity as ascertained by Martins da Silva et al. (2016) from grassland to forest, which was verified here only on a subset of functional traits.

The absence of an overall trend of increasing functional diversity suggests that other factors than niche variety (thought to act on the whole set of traits) could be involved, too, and that with some degree of trait specificity. It has been shown that functional diversity varies according to (i) the number of micro-niches to be occupied by species with different trait modalities, as expected from the adaptive value of functional traits (Massicotte et al., 2014; Bobrov et al., 2015) but also (ii) direct species interactions leading to trait overdispersion and underdispersion (by comparison with null models) for negative and positive interactions, respectively (Widenfalk et al., 2016). Both processes (within-sample environmental filtering and cooperation/competition) are not mutually exclusive, because any increase in the number of available niches would contribute to decrease the intensity of competition through niche partitioning (Anderson, 1978), pointing to some incertitude in the balance between both processes (and thus some confusion in the conclusions) in the absence of precise measurements of niche variety within samples and of niche overlapping between species (Astor et al., 2014). The impact of predation on functional diversity has been neglected in soil community ecology, although selective predation and competition release are known as routes for negative and positive top-down effects of predation on functional diversity, respectively (Helenius et al., 2015).

We also observed increases in trait diversity from spoil tips to their surrounding environments (Fig. 3, Table 3). In particular, trichobothria diversity showed a strong increase, at a very high level of significance $(P<0.0001)$, independent of successional stages (where no change was 
observed). This urged us to analyse this trend with more precision. As developed in Appendix C, we showed that trait diversity was not independent of mean trait values (CWM) and thus should be interpreted with care. Trait diversity decreases when CWMs approach either minimum or maximum values, with a maximum at medium CWM values. This means that trait diversity gives erroneous information when species share medium trait modalities in a community: trait diversity will be always higher at medium values of CWM. In the above example of the presence/absence of trichobothria, the increase in trait diversity between spoil tips and their surrounding environment (Table 3 ) is related to the high contrast in CWM values for this trait between spoil tips $(0.14$, not far from 0 , indicating the dominant contribution of endogeic life forms) and their surrounding environment (0.21, farther from 0 , indicating a higher contribution of epigeic life forms).

\subsection{Which criteria are better for the assessment of environmental effects on collembolan} communities: species, CWMs, or trait diversities?

We showed that species were influenced to a great extent by the site effect while CWMs were not, thus supporting our Hypothesis H3 (Table 4). This result is worthy of notice as it might indicate that when environmental effects are to be tested on a variety of sites, even within a common regional species pool, results may be strongly influenced by spatial factors, blurring potential effects of environmental filters, hence the need for partialling out spatial variation by more or less sophisticated methods (Martins da Silva et al., 2012; Ingimarsdóttir et al., 2012; Gao et al., 2014). However, some studies showed that functional traits could be also affected by spatial factors, even to a higher extent than species (Widenfalk et al., 2016). This can be due either to spatiallyanchored environmental variation (Widenfalk et al., 2015) or to dispersal limitation of some traits (Alday et al., 2011; Malmström, 2012). In the present study, the fact that traits did not reveal any significant variation among sites might indicate that spoil tips (and their surrounding environments) have already reached equilibrium from the point of view of mean trait values. This does not mean that species reached the equilibrium at community level, rather that the addition of new species will 
probably not change mean functional trait values at community level, and thus most functional processes mediated by these traits (Malmström, 2012), and that despite of the fact that studied traits were only a subset of the complete set of functional traits.

A cursory examination of Table 4 clearly indicates that species display many more significant effects than traits: all tests with species, to the exception of test 11 (testing pure soil effects), were significant, and all at the highest level of significance $(P<0.0001)$. The high sensitivity of species to all kinds of influences, whether spatial, environmental or historical (Ponge et al., 2003; Ingimarsdóttir et al., 2012; Maaß et al., 2015) should be acknowledged, but traits seem to be more robust than species to assess the effect of environmental parameters at community level, for instance in the presence of strong spatial influences (Fukami et al., 2005; Bokhorst et al., 2012). In our study, we were able to show (at least within the limits of our environmental records) that 'terril' effects on traits, and not successional effects, were mediated by soil (in particular coarser texture), which would have been more difficult to show with the only help of species composition. Thus collembolan functional traits, despite still insufficient knowledge about trait/function relationships (Grubert et al., 2016), may allow disentangling spatial and environmental effects more easily than species.

Despite the abovementioned methodological (non-monotonous relationship with CWM) and conceptual (competition versus niche availability) limits in the interpretation of functional diversity, Table 4 suggests that trait diversity is more informative than community-level mean trait values (CWM), by the higher number of significant tests. It has been underlined in several instances in the Results section that trait diversities showed results intermediate between species presence/absence and CWMs. This means that functional diversity (whether single- or multi-trait) is driven by processes in which both species and traits are involved (Mayfield et al., 2010). It is well-known that most functional diversity indices increase with species richness even when they are built independently from it (Laliberté and Legendre, 2010; Mouchet et al., 2010), although exceptions occur (Mayfield et al., 2010; Villéger et al., 2010; Mouchet et al., 2010). This relationship was verified on our data 
1 (Spearman rank test, $r_{s}=0.36, P<0.01$ ), meaning that functional diversity increases when species are

2 added, whether abundant or not, while community-weighted mean trait values (CWM), being

3 weighted by the relative abundance of species, are more sensitive to dominant than to subordinate species (Grime, 1998). In fact, average functional trait values (CWMs) are better indicators of actual environmental effects and ecosystem processes than trait diversity, while trait diversity better indicates the potential of the community to resist environmental hazards, in other words its resilience (Mason et al., 2005; Mayfield et al., 2010; Villéger et al., 2010).

\section{Conclusion}

Colliery heaps (or coal mine spoil tips) seem to be a good model for studying environmental filtering of traits and trait diversity at community level, by their high contrast with the surrounding environment, in particular concerning soil and microclimate conditions. They exert a high selection pressure, by forcing invertebrates to live in the soil rather than at the surface, favouring trait modalities linked to subterranean life, e.g. decreased size, absence or reduction of visual and jumping organs and reproduction by parthenogenesis. Parallel changes could be observed in spoil tips and their surrounding environment according to the concomitant development of vegetation and soil, with an increase in diversity for most (although not all) functional traits and in the representation of trait modalities linked to subterranean life. We also showed that a focus on traits rather than on species allows better discerning community responses to environmental factors at regional scale.

\section{Acknowledgements}

We warmly acknowledge the Métropole Européenne de Lille for its financial support, Mikhail Potapow for its help in the identification of Istomidae spp., Rafael Jordana and Enrique Baquero for their help in the identification of Pseudosinella spp., and Charles Gers, Frans Janssens, David Russel and Laszlo Danyi for their sharp advices. 


\section{References}

Addison, J.A., Trofymow, J.A., Marshall, V.G., 2003. Abundance, species diversity, and community structure of Collembola in successional coastal temperate forests on Vancouver Island, Canada. Appl. Soil Ecol. 24, 233-246.

Alday, J.G., Pallavicini, Y., Marrs, R.H., Martínez-Ruiz, C., 2011. Functional groups and dispersal strategies as guides for predicting vegetation dynamics on reclaimed mines. Plant Ecol. 212, $1759-1775$.

Altner, H., Thies, G., 1976. The postantennal organ: a specialized unicellular sensory input to the protocerebrum in Apterygotan insects (Collembola). Cell Tiss. Res. 167, 97-110.

Anderson, J.M., 1978. Competition between two unrelated species of soil Cryptostigmata (Acari) in experimental microscosms. J. Anim. Ecol. 47, 787-803.

Ashcroft, M.B., Gollan, J.R., Warton, D.I., Ramp, D., 2012. A novel approach to quantify and locate potential microrefugia using topoclimate, climate stability, and isolation from the matrix. Global Change Biol. 18, 1866-1879.

Astor, T., Strengbom, J., Berg, M.P., Lenoir, L., Marteinsdóttir, B., Bengtsson, J., 2014. Underdispersion and overdispersion of traits in terrestrial snail communities on islands. Ecol. Evol. 4, 2090-2102.

Auclerc, A., Libourel, P.A., Salmon, S., Bels, V., Ponge, J.F., 2010. Assessment of movement patterns in Folsomia candida (Hexapoda: Collembola) in the presence of food. Soil Biol. Biochem. 42, 657-659.

Bell, F.G., Bullock, S.E.T., Hälbich, T.F.J., Lindsay, P., 2001. Environmental impacts associated with an abandoned mine in the Witbank Coalfield, South Africa. Int. J. Coal Geol. 45, 195-216. 
Berg, M.P., Kniese, J.P., Bedaux, J.J.M., Verhoef, H.A., 1998. Dynamics and stratification of functional groups of micro- and mesoarthropods in the organic layer of a Scots pine forest. Biol. Fertil. Soils $26,268-284$.

Bispo, A., Cluzeau, D., Creamer, R., Dombos, M., Graefe, U., Krogh, P., Sousa, J.P., Pérès, G., Rutgers, M., Winding, A., Römbke, J., 2009. Indicators for monitoring soil biodiversity. Integr. Environ. Assess. Manag. 5, 717-719.

Bobrov, A.A., Zaitsev, A.S., Wolters, V., 2015. Shifts in soil testate amoeba communities associated with forest diversification. Microb. Ecol. 69, 884-894.

Bokhorst, S., Phoenix, G.K., Bjerke, J.W., Callaghan, T.V., Huyer-Brugman, F., Berg, M.P., 2012. Extreme winter warming events more negatively impact small rather than large soil fauna: shift in community composition explained by traits not taxa. Global Chang Biol. 18, 11521162.

Botta-Dukát, Z., 2005. Rao's quadratic entropy as a measure of functional diversity based on multiple traits. J. Veg. Sci. 16, 533-540.

Bretfeld, G., 1999. Synopses on Palaearctic Collembola. Symphypleona. Museum of Natural History Görlitz, Senckenberg.

Chahartaghi, M., Langel, R., Scheu, S., Ruess, L., 2005. Feeding guilds in Collembola based on nitrogen stable isotope ratios. Soil Biol. Biochem. 37, 1718-1725.

Chahartaghi, M., Scheu, S., Ruess, L., 2006. Sex ratio and mode of reproduction in Collembola of an oak-beech forest. Pedobiologia 50, 331-340.

Chamberlain, P.M., McNamara, N.P., Chaplow, J., Stott, A.W., Black, H.I.J., 2006. Translocation of surface litter carbon into soil by Collembola. Soil Biol. Biochem. 38, 2655-2664. 
1 Champely, S., Chessel, D., 2002. Measuring biological diversity using Euclidean metrics. Env. Ecol.

2 Statistics 9, 167-177.

Chang, L., Wu, H.T., Wu, D.H., Sun, X., 2013. Effect of tillage and farming management on Collembola in marsh soils. Appl. Soil Ecol. 64, 112-117.

Chernova, N.M., Potapov, M.B., Savenkova, Y.Y., Bokova, A.I., 2010. Ecological significance of parthenogenesis in Collembola. Entomol. Rev. 90, 23-38.

Cronberg, N., Natcheva, R., Hedlund, K., 2006. Microarthropods mediate sperm transfer in mosses. Science 313, 1255.

Debinski, D.M., Brussard, P.F., 1994. Using biodiversity data to assess species-habitat relationships in Glacier National Park, Montana. Ecol. Appl. 4, 833-843.

Dettner, K., Scheuerlein, A., Fabian, P., Schulz, S., Francke, W., 1996. Chemical defense of giant springtail Tetrodotonphora bielanensis (Waga) (Insecta: Collembola). J. Chem. Ecol. 22, 10511074.

Down, C.G., 1973. Life form succession in plant communities on colliery waste tips. Environ. Pollut. 5, $19-22$.

Dunger, W., Schlitt, B., 2011. Synopses on Palaearctic Collembola. Onychiuroidea: Tullbergiidae. Museum of Natural History Görlitz, Senckenberg.

Dunger, W., Schulz, H.J., Zimdars, B., 2002. Colonization behaviour of Collembola under different conditions of dispersal. Pedobiologia 46, 316-327.

Dunger, W., Schulz, H.J., Zimdars, B., Hohberg, K., 2004. Changes in collembolan species composition in Eastern German mine sites over fifty years of primary succession. Pedobiologia 48, 503517. 
Dunger, W., Voigtländer, K., 2005. Assessment of biological soil quality in wooded reclaimed mine sites. Geoderma 129, 32-44.

Dunger, W., Wanner, M., Hauser, H., Hohberg, K., Schulz, H.J., Schwalbe, T., Seifert, B., Vogel, J., Voigtländer, K., Zimdars, B., Zulka, K.P., 2001. Development of soil fauna at mine sites during 46 years after afforestation. Pedobiologia 45, 243-271.

Emmer, I.M., Sevink, J., 1994. Temporal and vertical changes in the humus form profile during a primary succession of Pinus sylvestris. Plant Soil 167, 281-295.

Filser, J., 2002. The role of Collembola in carbon and nitrogen cycling in soil. Pedobiologia 46, 234245.

Frouz, J., Pižl, V., Tajovský, K., Starý, J., Holec, M., Materna, J., 2013. Soil macro- and mesofauna succession in post-mining sites and other disturbed areas, in: Frouz, J. (Ed.), Soil biota and ecosystem development in post-mining sites. CRC Press, Boca Raton, pp. 216-235.

Fukami, T., Bezemer, T.M., Mortimer, S.R., Van der Putten, W.H., 2005. Species divergence and trait convergence in experimental plant community assembly. Ecol. Lett. 8, 1283-1290.

Gao, M.X., Zhang, X.P., Liu, D., Wu, D.H., 2014. Relative roles of spatial factors, environmental filtering and biotic interactions in fine-scale structuring of a soil mite community. Soil Biol. Biochem. 79, 68-77.

Garnier, É., Cortez, J., Billès, G., Navas, M.L., Roumet, C., Debussche, M., Laurent, G., Blanchard, A., Aubry, D., Bellman, A., Neill, C., Toussaint, J.P., 2004. Plant functional markers capture ecosystem properties during secondary succession. Ecology 85, 2630-2637.

Gisin H., 1960. Collembolenfauna Europas. Muséum d'Histoire Naturelle, Geneva.

Godin, J., 2002. Degré de rareté, évolution de la distribution et particularités de l’herpétofaune de la Région Nord-Pas-de-Calais. Bull. Soc. Herpét. Fr. 104, 16-35. 
Greenslade, P., Majer, J.D., 1993. Recolonization by Collembola of rehabilitated bauxite mines in Western Australia. Australian J. Ecol. 18, 385-394.

Grime, J.P., 1998. Benefits of plant diversity to ecosystems: immediate, filter and founder effects. J. Ecol. 86, 902-910.

Grubert, D., Butenschoen, O., Maraun, M., Scheu, S., 2016. Understanding earthworm-Collembola interactions and their importance for ecosystem processes needs consideration of species identity. Eur. J. Soil Biol. 77, 60-67.

Hågvar, S., 1990. Reactions to soil acidification in microarthropods: is competition a key factor? Biol. Fertil. Soils 9, 178-181.

Heiniger, C., Barot, S., Ponge, J.F., Salmon, S., Meriguet, J., Carmignac, D., Suillerot, M., Dubs, F., 2015. Collembolan preferences for soil and microclimate in forest and pasture communities. Soil Biol. Biochem. 86, 181-192.

Helenius, L.K., Padrós, A.A., Leskinen, E., Lehtonen, H., Nurminen, L., 2015. Strategies of zooplanktivory shape the dynamics and diversity of littoral plankton communities: a mesocosm approach. Ecol. Evol. 5, 2021-2035.

Hertzberg, K., 1997. Migration of Collembola in a patchy environment. Pedobiologia 41, 494-505.

Hopkin, S.P., 1997. Biology of the Springtails. Oxford University Press, Oxford.

Hopkin, S.P., 2007. A Key to the Collembola (Springtails) of Britain and Ireland. Field Studies Council, Shrewsbury.

Hubbert, M.K., 1956. Nuclear Energy and the Fossil Fuel. American Petroleum Institute, Washington.

Hutson, B.R., 1980. Colonization of industrial reclamation sites by Acari, Collembola and other invertebrates. J. Appl. Ecol. 17, 255-275. 
Ingimarsdóttir, M., Caruso, T., Ripa, J., Magnúsdóttir, Ó.B., Migliorini, M., Hedlund, K., 2012. Primary assembly of soil communities: disentangling the effect of dispersal and local environment. Oecologia $170,745-754$.

ISO, 1995a. Soil quality: determination of organic and total carbon after dry combustion (elementary analysis). International Organization for Standardization, Geneva.

ISO, 1995b. Soil quality: determination of total nitrogen (modified Kjeldahl method). International Organization for Standardization, Geneva.

ISO, 2005. Soil quality: determination of pH. International Organization for Standardization, Geneva.

ISO, 2009. Soil quality: determination of particle size distribution in mineral soil material (method by sieving and sedimentation). International Organization for Standardization, Geneva.

Jordana, R., 2012. Synopses on Palaearctic Collembola. Capbryinae and Entomobryi. Museum of Natural History Görlitz, Senckenberg.

Kahmen, S., Poschlod, P., 2004. Plant functional trait responses to grassland succession over 25 years. J. Veg. Sci. 15, 21-32.

Kenkel, N.C., 2006. On selecting an appropriate multivariate analysis. Can. J. Plant. Sci. 86, 663-676.

Kent, M., 1982. Plant growth problems in colliery spoil reclamation: a review. Appl. Geogr. 2, 83-107.

Kirmer, A., Tischew, S., Ozinga, W.A., von Lampe, M., Baasch, A., Van Groenendael, J.M., 2008. Importance of regional species pools and functional traits in colonization processes: predicting re-colonization after large-scale destruction of ecosystems. J. Appl. Ecol. 45, 15231530. 
Kleyer, M., Dray, S., de Bello, F., Lepš, J., Pakeman, R.J., Strauss, B., Thuiller, W., Lavorel, S., 2012. Assessing species and community functional responses to environmental gradients: which multivariate methods? J. Veg. Sci. 23, 805-821.

Koehler, H., Munderloh, E., Hofmann, S., 1995. Soil microarthropods (Acari, Collembola) from beach and dune: characteristics and ecosystem context. J. Coastal Conserv. 1, 77-86.

Krab, E.J., Oorsprong, H., Berg, M.P., Cornelissen, J.H.C., 2010. Turning northern peatlands upside down: disentangling microclimate and substrate quality effects on vertical distribution of Collembola. Funct. Ecol. 24, 1362-1369.

Ladoucette, P. de, 2004. Charbonnages de France et la société française. Réalités Industrielles Mai 2004, 7-19. http://www.annales.org/ri/2004/mai/ladoucette07-17.pdf (accessed 21.12.16).

Laliberté, É., Legendre, P., 2010. A distance-based framework for measuring functional diversity from multiple traits. Ecology 91, 299-305.

Larsen, T., Schjønning, P., Axelsen, J., 2004. The impact of soil compaction on euedaphic Collembola. Appl. Soil Ecol. 26, 273-281.

Lavorel, S., Garnier, É., 2002. Predicting changes in community composition and ecosystem functioning from plant traits: revisiting the Holy Grail. Funct. Ecol. 16, 545-556.

Lee, D.W., 2002. Anthocyanins in leaves: distribution, phylogeny and development. Adv. Bot. Res; 37, 37-53.

Leinaas, H.P., 2002. UV tolerance, pigmentation and life forms in High Arctic Collembola, in: Hessen, D.O. (Eds.), UV Radiation and Arctic Ecosystems. Springer, Berlin, pp. 123-134.

Lemoine, G., 2012. Interêt, gestion, protection et valorisation des terrils miniers dans le Nord-Pas-deCalais. Ann. Soc. Géol. Nord 19, 1-8. 
Loranger, G., G., Bandyopadhyaya, I., Razaka, B., Ponge, J.F., 2001. Does soil acidity explain altitudinal sequences in collembolan communities ? Soil Biol. Biochem. 33, 381-393.

Maaß, S., Maraun, M., Scheu, S., Rillig, M.C., Caruso, T., 2015. Environmental filtering vs. resourcebased niche partitioning in diverse soil animal assemblages. Soil Biol. Biochem. 85, 145-152.

Malmström, A., 2012. Life-history traits predict recovery patterns in Collembola species after fire: a 10 year study. Appl. Soil Ecol. 56, 35-42.

Markowicz, A., Woźniak, G., Borymski, S., Piotrowska-Seget, Z., Chmura, D., 2015. Links in the functional diversity between soil microorganisms and plant communities during natural succession in coal mine spoil heaps. Ecol. Res. 30, 1005-1014.

Martins da Silva, P., Berg, M.P., Serrano, A.R.M., Dubs, F., Sousa, J.P., 2012. Environmental factors at different spatial scales governing soil fauna community patterns in fragmented forests. Landscape Ecol. 27, 1337-1349.

Martins da Silva, P., Carvalho, F., Dirilgen, T., Stone, D., Creamer, R., Bolger, T., Sousa, J.P., 2016. Traits of collembolan life-form indicate land use types and soil properties across an European transect. Appl. Soil Ecol. 97, 69-77.

Mason, N.W.H., Mouillot, D., Lee, W.G., Wilson, J.B., 2005. Functional richness, functional evenness and functional divergence: the primary components of functional diversity. Oikos 111, 112118.

Massicotte, P., Frenette, J.J., Proulx, R., Pinel-Alloul, B., Bertolo, A., 2014. Riverscape heterogeneity explains spatial variation in zooplankton functional evenness and biomass in a large river ecosystem. Landcape Ecol. 29, 67-79.

Mayfield, M.M., Bonser, S.P., Morgan, J.W., Aubin, I., McNamara, S., Vesk, P.A., 2010. What does species richness tell us about functional trait diversity? Predictions and evidence for 

responses of species and functional trait diversity to land-use change. Global Ecol. Biogeogr. $19,423-431$.

Mitschunas, N., Wagner, M., Filser, J., 2006. Evidence for a positive influence of fungivorous soil invertebrates on the seed bank persistence of grassland species. J. Ecol. 94, 791-800.

Molyneux, J.K., 1963. Some ecological aspects of colliery waste heaps around Wigan, South Wales. J. Ecol. 51, 315-321.

Moore, F.R., Luxton, M., 1986. The collembolan fauna of two coal shale tips in north-west England. Pedobiologia 29, 359-366.

Moretti, M., Legg, C., 2009. Combining plant and animal traits to assess community functional responses to disturbances. Ecography 32, 299-309.

Mouchet, M.A., Villéger, S., Mason, N.W.H., Mouillot, D., 2010. Functional diversity measures: an overview of their redundancy and their ability to discriminate community assembly rules. Funct. Ecol. 24, 867-876.

Murray, P.J., Clegg, C.D., Crotty, F.V., de la Fuente Martínez, N., Williams, J.K., Blackshaw, R.P., 2009. Dissipation of bacterially derived $\mathrm{C}$ and $\mathrm{N}$ through the meso- and macrofauna of a grassland soil. Soil Biol. Biochem. 41, 1146-1150.

Negri, I., 2004. Spatial distribution of Collembola in presence and absence of a predator. Pedobiologia 48, 585-588.

$\varnothing$ kland, R.H., 1996. Are ordination and constrained ordination alternative or complementary strategies in general ecological studies? J. Veg. Sci. 7, 289-292.

Parisi, V., Menta, C., Gardi, C., Jacomini, C., Mozzanica, E., 2005. Microarthropod communities as a tool to assess soil quality and biodiversity: a new approach in Italy. Agr. Ecosyst. Environ. 105, 323-333. 
Petchey, O.L., Gaston, K.J., 2002. Functional diversity (FD), species richness and community composition. Ecol. Lett. 5, 402-411.

Petit, D., 1980. La végétation des terrils du Nord de la France: écologie, phytosociologie, dynamisme. Unpublished doctorate thesis, University of Lille, France. https://ori-nuxeo.univlille1.fr/nuxeo/site/esupversions/771424b7-360f-4e3d-a438-d306b9ea3947 (accessed 11.04.17).

Petit, D., 1983. Les groupements végétaux colonisateurs des terrils du charbonnage du Nord de la France: intérêt de leur étude. Coll. Phytosociol. 12, 156-178.

Pey, B., Nahmani, J., Auclerc, A., Capowiez, Y., Cluzeau, D., Cortet, J., Decaëns, T., Deharveng, L., Dubs, F., Joimel, S., Briard, C., Grumiaux, F., Laporte, M.A., Pasquet, A., Pelosi, C., Pernin, C., Ponge, J.F., Salmon, S., Santorufo, L., Hedde, M., 2014. Current use and future needs for soil invertebrate functional traits in community ecology. Basic. Appl. Ecol. 15, 194-206.

Piekarska-Stachowiak, A., Szary, M., Ziemer, B., Besenyei, L., Woźniak, G., 2014. An application of the plant functional group concept to restoration practice on coal mine spoil heaps. Ecol. Res. 29, 843-853.

Ponge, J.F., 1993. Biocenoses of Collembola in atlantic temperate grass-woodland ecosystems. Pedobiologia 37, 223-244.

Ponge, J.F., 2000. Vertical distribution of Collembola (Hexapoda) and their food resources in organic horizons of beech forests. Biol. Fertil. Soils 32, 508-522.

Ponge, J.F., Dubs, F., Gillet, S., Sousa, J.P., Lavelle, P., 2006. Decreased biodiversity in soil springtail communities: the importance of dispersal and landuse history in heterogeneous landscapes. Soil Biol. Biochem. 38, 1158-1161. 
Ponge, J.F., Gillet, S., Dubs, F., Fedoroff, É., Haese, L., Sousa, J.P., Lavelle, P., 2003. Collembolan communities as bioindicators of land use intensification. Soil Biol. Biochem. 35, 813-826.

Potapow, M., 2001. Synopses on Palaearctic Collembola. Isotomidae. Museum of Natural History Görlitz, Senckenberg.

Prinzing, A., Woas, S., 2003. Habitat use and stratification of Collembola and oribatid mites, in: Basset, Y., Novotny, V., Miller, S.E., Kitchling, R.L. (Eds.), Arthropods of Tropical Forests: Spatio-Temporal Dynamics and Resource Use in the Canopy. Cambridge University Press, Cambridge, pp. 271-281.

Rajaniemi, T.K., Goldberg, D.E., Turkington, R., Dyer, A.R., 2006. Quantitative partitioning of regional and local processes shaping regional diversity patterns. Ecol. Lett. 9, 121-128.

Rao, C.R., 1982. Diversity and dissimilarity coefficients: a unified approach. Theor. Pop. Biol. 21, 2443.

Ricotta, C., Moretti, M., 2011. CWM and Rao's quadratic diversity: a unified framework for functional ecology. Oecologia 167, 181-188.

Roff, D.A., Fairbairn, D.J., 2007. The evolution of trade-offs: where are we? J. Evol. Biol. 20, 433-447.

Rusek, J., 1998. Biodiversity of Collembola and their functional role in the ecosystem. Biodiv. Conserv. 7, 1207-1219.

Rusek, J., 2004. Collembola succession on deposits from a chemical factory. Pedobiologia 48, 519525.

Rusek, J., 2007. A new classification of Collembola and Protura life forms, in: Tajovský, K., Schlaghamerský, J., Pižl, V. (Eds.), Contributions to Soil Zoology in Central Europe II. Institute of Soil Zoology, Biology Centre, Academy of Sciences of the Czech Republic, České Budějovice, pp. 109-115. 
Salmon, S., Geoffroy, J.J., Ponge, J.F., 2005. Earthworms and Collembola relationships: effects of predatory centipedes and humus forms. Soil Biol. Biochem. 37, 487-495.

Salmon, S., Ponge, J.F., 2012. Species traits and habitats in springtail communities: a regional scale study. Pedobiologia 55, 295-301.

Salmon, S., Ponge, J.F., Gachet, S., Deharveng, L., Lefebvre, N., Delabrosse, F., 2014. Linking species, traits and habitat characteristics of Collembola at European scale. Soil Biol. Biochem. 75, 7385.

Salmon, S., Ponge, J.F., Van Straalen, N.M., 2002. Ionic identity of pore water influences pH preference in Collembola. Soil Biol. Biochem. 34, 1663-1667.

Santorufo, L., Cortet, J., Nahmani, J., Pernin, C., Salmon, S., Pernot, A., Morel, J.L., Maisto, G., 2015. Responses of functional and taxonomic collembolan community structure to site management in Mediterranean urban and surrounding areas. Eur. J. Soil Biol. 70, 46-57.

Schleuter, D., Daufresne, M., Massol, F., Argillier, C., 2010. A user's guide to functional diversity indices. Ecol. Monogr. 80, 469-484.

Spasojevic, M.J., Yablon, E.A., Oberle, B., Myers, J.A., 2014. Ontogenetic trait variation influences tree community assembly across environmental gradients. Ecosphere 5(10):129.

Thibaud, J.M., Schulz, H.J., da Gama Assalino, M.M., 2004. Synopses on Palaearctic Collembola. Hypogastruridae. Museum of Natural History Görlitz, Senckenberg.

Tischew, S., Baasch, A., Grunert, H., Kirmer, A., 2014. How to develop native plant communities in heavily altered ecosystems: examples from large-scale surface mining in Germany. Appl. Veg. Sci. 17, 288-301.

Troia, A., Raimondo, F.M., Mazzola, P., 2012. Mediterranean island biogeography: analysis of fern species distribution in the system of islets around Sicily. Plant Biosystems 146, 576-585. 
1

2

UNESCO, 2012. Nord-Pas de Calais Mining Basin. http://whc.unesco.org/en/list/1360 (accessed 11.04.17).

Usher, M.B., Balogun, R.A., 1966. A defence mechanism in Onychiurus (Collembola, Onychiuridae). Entom. Monthly Mag. 102, 237-238.

Van den Wollenberg, A.L., 1977. Redundancy Analysis: an alternative for canonical corresltion analysis. Psychometrika 42, 207-219.

Van Dooremalen, C., Berg, M.P., Ellers, M.P., 2013. Acclimation responses to temperature vary with vertical stratification: implications for vulnerability of soil-dwelling species to extreme temperature events. Global Change Biol. 19, 975-984.

Vannier, G., 1987. The porosphere as an ecological medium emphasized in Professor Ghilarov's work on soil animal adaptations. Biol. Fertil. Soils 3, 39-44.

Verhoef, H.A., Nagelkerke, C.J., Joosse, E.N.G., 1977. Aggregation pheromones in Collembola (Apterygota): a biotic cause of aggregation. Rev. Écol. Biol. Sol 14, 21-25.

Villéger, S., Ramos Miranda, J., Flores Hernández, D., Mouillot, D., 2010. Contrasting changes in taxonomic vs. Functional diversity of tropical fish communities after habitat degradation. Ecol. Appl. 20, 1512-1522.

Violle, C., Navas, M.L., Vile, D., Kazakou, E., Fortunel, C., Hummel, I., Garnier, É., 2007. Let the concept of trait be functional. Oikos 116, 882-892.

Wallwork, J.A., 1972. Distribution patterns and population dynamics of the micro-arthropods of a desert soil in southern California. J. Anim. Ecol. 41, 291-310.

Whitlock, D.S., Rickson, J., Humphries, R.N., Thompson, R., Tibbett, M., 2015. The influence of coal mine spoil physical properties on the spatial distribution of lichen-rich communities, in 
Fourie, A.B., Tibbett, M., Sawatsky, I., Van Zyl, D. (Eds.), Mine Closure 2015. InfoMine, Vancouver, pp. 1047-1059.

Widenfalk, L.A., Bengtsson, J., Berggren, Å., Zwiggelaar, K., Spijkman, E., Huyer-Brugman, F., Berg, M.P., 2015. Spatially-structured environmental filtering of collembolan traits in late successional salt marsh vegetation. Oecologia 179, 537-549.

Widenfalk, L.A., Malmström, A., Berg, M.P., Bengtsson, J., 2016. Small-scale Collembola community composition in a pine forest soil: overdispersion in functional traits indicates the importance of species interactions. Soil Biol. Biochem. 103, 52-62.

Winck, B.R., de Sá, E.L.Z., Rigotti, V.M., Chauvat, M., 2017. Relationship between land-use types and functional diversity of epigeic Collembola in Southern Brazil. Appl. Soil Ecol. 109, 49-59.

Zettel, J., 2000. Alpine Collembola: adaptations and strategies for survival in harsh environments. Zoology 102, 73-89.

Zinkler, D., Platthaus, J., 1996. Tolerance of soil-dwelling Collembola to high carbon dioxide concentrations. Eur. J. Entomol. 93, 443-450. 


\section{Figure captions}

2 Fig. 1. Principal components analysis. Projection of environment descriptors in the plane of the first two principal components. ENV = surrounding environment; $\mathrm{ST}$ = spoil tip.

Fig. 2. Principal components analysis. Projection of CWMs (Community Weighted Mean traits) in the plane of the first two principal components. See Table 2 for the list of trait modalities and the numerical values assigned to each of them.

Fig. 3. Principal components analysis. Projection of single-trait diversities (Rao's quadratic entropy) and functional diversity (multi-trait diversity) in the plane of the first two principal components. 


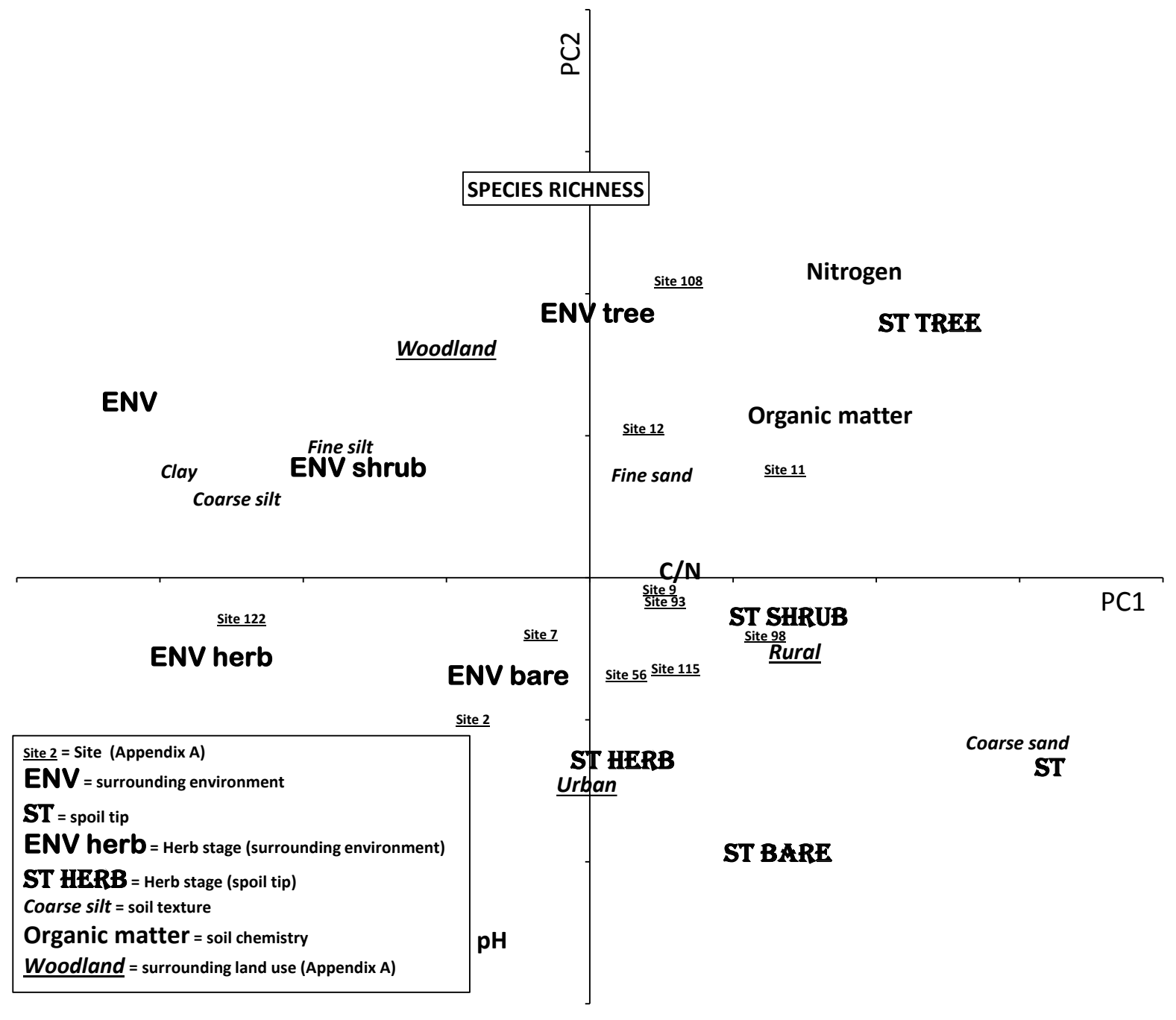

Fig. 1 


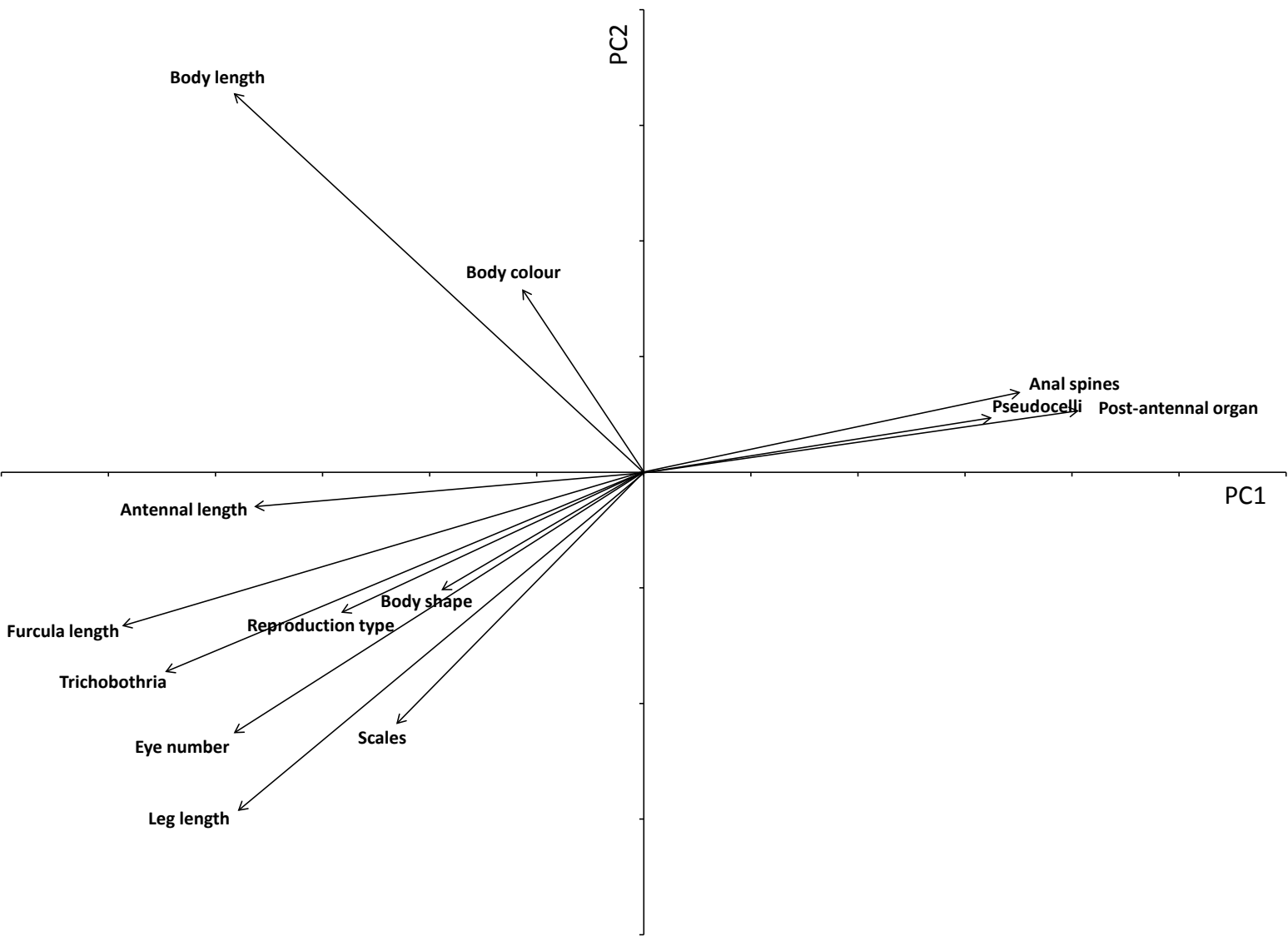

Fig. 2

3 


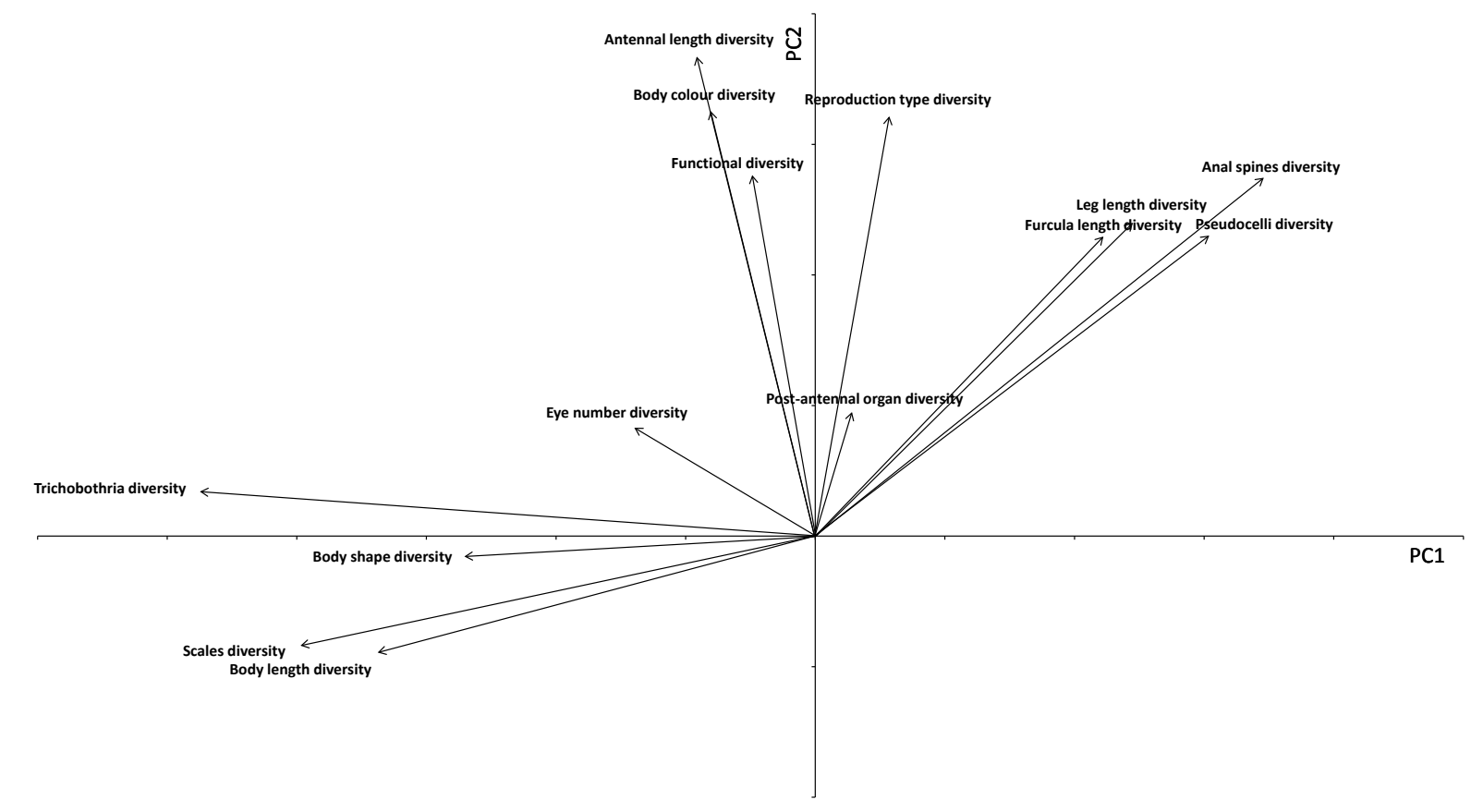

$2 \quad$ Fig. 3 
Table 1. Mean values ( \pm SE) of two first components of PCA (faunistic composition), numbers of species per sample (species richness) and main soil analyses according to primary (spoil tip versus environment) and secondary (successional stage) environmental factors. Comparisons among modalities were performed for each factor by Kruskal-Wallis rank tests (NS = not significant, $* \mathrm{P}<0.05, * * \mathrm{P}<0.01, * * * \mathrm{p}<0.0001, * * * * \mathrm{P}<0.0001$ ) followed by Dunn tests (different letters indicate significant differences among modalities after Bonferroni adjustment for multiple comparisons).

\begin{tabular}{|c|c|c|c|c|c|c|c|c|}
\hline & $\begin{array}{l}\text { Spoil tip } \\
(n=37)\end{array}$ & $\begin{array}{l}\text { Surrounding } \\
\text { environment } \\
(n=44)\end{array}$ & & $\begin{array}{l}\text { Bare } \\
(n=17)\end{array}$ & $\begin{array}{l}\text { Herb } \\
(n=36)\end{array}$ & $\begin{array}{l}\text { Shrub } \\
(n=9)\end{array}$ & $\begin{array}{l}\text { Tree } \\
(n=22)\end{array}$ & \\
\hline PC1 & $1.57 \pm 0.29^{a}$ & $-1.32 \pm 0.26^{b}$ & $* * * *$ & $0.64 \pm 0.34^{\mathrm{ab}}$ & $-1.15 \pm 0.27^{c}$ & $-0.65 \pm 1.04^{b c}$ & $1.51 \pm 0.46^{\mathrm{a}}$ & $* * * *$ \\
\hline PC2 & $-0.59 \pm 0.38^{b}$ & $0.50 \pm 0.30^{\mathrm{a}}$ & $* *$ & $-1.74 \pm 0.16^{c}$ & $-0.68 \pm 0.23^{b}$ & $0.62 \pm 0.36^{\mathrm{ab}}$ & $2.00 \pm 0.57^{\mathrm{a}}$ & $* * * *$ \\
\hline Sample species richness & $11.5 \pm 0.8$ & $12.3 \pm 0.6$ & NS & $7.4 \pm 0.8^{b}$ & $11.9 \pm 0.7^{\mathrm{a}}$ & $13.9 \pm 1.2^{\mathrm{a}}$ & $14.0 \pm 0.6^{\mathrm{a}}$ & $* * * *$ \\
\hline $\mathrm{pH}$ & $6.9 \pm 0.2$ & $6.8 \pm 0.2$ & NS & $7.7 \pm 0.2^{\mathrm{a}}$ & $6.8 \pm 0.2^{b}$ & $7.3 \pm 0.2^{\mathrm{ab}}$ & $6.2 \pm 0.2^{b}$ & $* * *$ \\
\hline Organic matter (\%о) & $68.3 \pm 6.5^{\mathrm{a}}$ & $50.1 \pm 3.7^{b}$ & $*$ & $40.8 \pm 6.4^{b}$ & $50.0 \pm 4.2^{b}$ & $62.1 \pm 8.9^{\mathrm{ab}}$ & $81.1 \pm 8.3^{\mathrm{a}}$ & $* * * *$ \\
\hline Nitrogen $(\% \circ)$ & $3.59 \pm 0.22^{\mathrm{a}}$ & $3.10 \pm 0.26^{b}$ & $*$ & $2.52 \pm 0.23^{b}$ & $2.94 \pm 0.23^{b}$ & $3.06 \pm 0.27^{\mathrm{ab}}$ & $4.49 \pm 0.37^{\mathrm{a}}$ & $* * *$ \\
\hline $\mathrm{C}: \mathrm{N}$ & $9.8 \pm 3.5$ & $7.9 \pm 0.8$ & NS & $7.4 \pm 1.3$ & $8.0 \pm 0.9$ & $7.7 \pm 0.9$ & $11.2 \pm 1.0$ & NS \\
\hline Coarse sand (\%) & $51.2 \pm 2.8^{\mathrm{a}}$ & $14.3 \pm 1.5^{b}$ & $* * * *$ & $50.9 \pm 6.9^{\mathrm{a}}$ & $23.2 \pm 3.2^{b}$ & $30.5 \pm 7.8^{\mathrm{ab}}$ & $31.6 \pm 4.4^{\mathrm{ab}}$ & $* *$ \\
\hline Fine sand (\%) & $13.4 \pm 0.5$ & $15.8 \pm 1.0$ & NS & $13.6 \pm 1.3$ & $14.4 \pm 0.8$ & $13.9 \pm 1.4$ & $16.1 \pm 1.5$ & NS \\
\hline Coarse silt (\%) & $14.3 \pm 1.9^{b}$ & $24.7 \pm 1.5^{\mathrm{a}}$ & $* * * *$ & $9.4 \pm 1.4^{b}$ & $23.7 \pm 2.0^{\mathrm{a}}$ & $21.2 \pm 3.9^{\mathrm{a}}$ & $20.2 \pm 2.4^{\mathrm{a}}$ & $* * * *$ \\
\hline Fine silt (\%) & $12.6 \pm 0.7^{b}$ & $25.5 \pm 1.7^{\mathrm{a}}$ & $* * * *$ & $17.4 \pm 3.7$ & $21.5 \pm 1.7$ & $18.2 \pm 3.5$ & $18.3 \pm 2.0$ & NS \\
\hline Clay (\%) & $8.6 \pm 0.7^{b}$ & $19.7 \pm 1.0^{\mathrm{a}}$ & $* * * *$ & $8.7 \pm 2.1^{b}$ & $17.2 \pm 1.2^{\mathrm{a}}$ & $16.2 \pm 3.2^{\mathrm{ab}}$ & $13.8 \pm 1.5^{\mathrm{ab}}$ & $* *$ \\
\hline
\end{tabular}


Table 2. Mean values ( \pm SE) of community-weighted mean (CWM) functional traits according to primary (spoil tip versus environment) and secondary (successional stage) environmental factors. Comparisons among modalities were performed for each factor by Kruskal-Wallis rank tests ( $\mathrm{NS}=$ not significant, ${ }^{*} \mathrm{P}<0.05,{ }^{* *} \mathrm{P}<0.01,{ }^{* * *} \mathrm{P}<0.001,{ }^{* * * *} \mathrm{P}<0.0001$ ) followed by Dunn tests (different letters indicate significant differences among modalities after Bonferroni adjustment for multiple comparisons).

\begin{tabular}{|c|c|c|c|c|c|c|c|c|c|}
\hline Functional trait & Functions fulfilled & $\begin{array}{l}\text { Spoil tip } \\
(n=37)\end{array}$ & $\begin{array}{l}\text { Surrounding } \\
\text { environmen } \\
(\mathrm{n}=44)\end{array}$ & & $\begin{array}{l}\text { Bare } \\
(n=17)\end{array}$ & $\begin{array}{l}\text { Herb } \\
(n=36)\end{array}$ & $\begin{array}{l}\text { Shrub } \\
(n=9)\end{array}$ & $\begin{array}{l}\text { Tree } \\
(n=22)\end{array}$ & \\
\hline $\begin{array}{l}\text { Reproduction type } \\
\text { (1: parthenogenetic; 2: sexual) }\end{array}$ & Reproduction & $1.60 \pm 0.04^{b}$ & $1.73 \pm 0.03^{a}$ & * & $1.70 \pm 0.08^{\mathrm{ab}}$ & $1.77 \pm 0.02^{\mathrm{a}}$ & $1.57 \pm 0.06^{\mathrm{ab}}$ & $1.54 \pm 0.05^{b}$ & ***** \\
\hline $\begin{array}{l}\text { Body length } \\
(1:<1 \mathrm{~mm} ; 2: 1-2 \mathrm{~mm} ; 3: 2-3 \mathrm{~mm} ; 4:>3 \mathrm{~mm}\end{array}$ & $\begin{array}{l}\text { Feeding, excretion, active and passive } \\
\text { dispersal, respiration }\end{array}$ & $2.12 \pm 0.05^{b}$ & $2.35 \pm 0.04^{a}$ & ** & $2.12 \pm 0.07$ & $2.31 \pm 0.06$ & $2.16 \pm 0.11$ & $2.26 \pm 0.06$ & NS \\
\hline $\begin{array}{l}\text { Body shape } \\
\text { (1: very slender; 2: slender; } 3 \text { : stocky; } 4 \text { : globular) }\end{array}$ & $\begin{array}{l}\text { Passive dispersal (lift-to-drag ratio), } \\
\text { protection against desiccation } \\
\text { (surface/volume ratio) }\end{array}$ & $2.14 \pm 0.06$ & $2.20 \pm 0.04$ & NS & $2.19 \pm 0.14$ & $2.22 \pm 0.04$ & $2.26 \pm 0.09$ & $2.07 \pm 0.03$ & NS \\
\hline $\begin{array}{l}\text { Body colour } \\
\text { (1: pale-coloured; 2: bright-coloured; 3: dark-coloured) }\end{array}$ & Protection against UV-radiation & $2.18 \pm 0.09$ & $2.24 \pm 0.05$ & NS & $1.92 \pm 0.18$ & $2.29 \pm 0.05$ & $2.22 \pm 0.14$ & $2.26 \pm 0.07$ & NS \\
\hline $\begin{array}{l}\text { Scales } \\
\text { (1: absent; 2: present) }\end{array}$ & Protection against desiccation & $1.18 \pm 0.04^{b}$ & $1.24 \pm 0.02^{\mathrm{a}}$ & ** & $1.34 \pm 0.08$ & $1.22 \pm 0.03$ & $1.17 \pm 0.04$ & $1.13 \pm 0.02$ & NS \\
\hline $\begin{array}{l}\text { Antennal length } \\
(1:<\text { head diagonal; } 2: 1-2 \text { head diagonals; } 3:>2 \text { head diagonals) }\end{array}$ & $\begin{array}{l}\text { Reception of olfactory, heat and } \\
\text { tactile signals }\end{array}$ & $1.56 \pm 0.05^{\mathrm{b}}$ & $1.75 \pm 0.03^{\mathrm{a}}$ & *** & $1.66 \pm 0.09^{\mathrm{ab}}$ & $1.76 \pm 0.03^{\mathrm{a}}$ & $1.63 \pm 0.08^{\mathrm{ab}}$ & $1.51 \pm 0.05^{\mathrm{b}}$ & $* *$ \\
\hline $\begin{array}{l}\text { Leg length } \\
(1: \text { leg III/body }<0.3 ; 2: \text { leg III/body } \geq 0.3)\end{array}$ & Locomotion & $1.68 \pm 0.04$ & $1.75 \pm 0.03$ & NS & $1.74 \pm 0.08^{\mathrm{ab}}$ & $1.78 \pm 0.03^{\mathrm{a}}$ & $1.74 \pm 0.05^{\text {ab }}$ & $1.61 \pm 0.05^{\mathrm{b}}$ & * \\
\hline $\begin{array}{l}\text { Furcula length } \\
\text { (1: absent or vestigial; 2: Abd III anterior not reached; } 3: \text { Abd III anterior reached) }\end{array}$ & Jump (dispersal, predator avoidance) & $2.42 \pm 0.07^{\mathrm{b}}$ & $2.63 \pm 0.04^{a}$ & * & $2.45 \pm 0.15^{\mathrm{ab}}$ & $2.65 \pm 0.05^{\mathrm{a}}$ & $2.57 \pm 0.08^{\mathrm{ab}}$ & $2.39 \pm 0.06^{\mathrm{b}}$ & * \\
\hline $\begin{array}{l}\text { Eye number } \\
(1: 0 ; 2: 1-5 ; 3:>5)\end{array}$ & Vision & $2.18 \pm 0.07$ & $2.35 \pm 0.05$ & NS & $2.14 \pm 0.15^{b}$ & $2.51 \pm 0.04^{\mathrm{a}}$ & $2.17 \pm 0.07^{\mathrm{b}}$ & $2.02 \pm 0.04^{\mathrm{b}}$ & $* * * *$ \\
\hline $\begin{array}{l}\text { Pseudocella } \\
\text { (1: absent; 2: present) }\end{array}$ & Predator repellence & $1.14 \pm 0.03$ & $1.10 \pm 0.01$ & NS & $1.18 \pm 0.07^{\mathrm{ab}}$ & $1.07 \pm 0.01^{\mathrm{b}}$ & $1.08 \pm 0.02^{\mathrm{ab}}$ & $1.17 \pm 0.02^{\mathrm{a}}$ & ** \\
\hline $\begin{array}{l}\text { Post-antennal organ } \\
\text { (1: absent; 2: simple; } 3 \text { : compound) }\end{array}$ & $\begin{array}{l}\text { Reception of olfactory signals (still not } \\
\text { fully known) }\end{array}$ & $1.87 \pm 0.07^{\mathrm{a}}$ & $1.68 \pm 0.04^{\mathrm{b}}$ & $* *$ & $1.70 \pm 0.14^{\mathrm{ab}}$ & $1.73 \pm 0.06^{\mathrm{b}}$ & $1.65 \pm 0.07^{\mathrm{ab}}$ & $1.90 \pm 0.04^{\mathrm{a}}$ & $*$ \\
\hline $\begin{array}{l}\text { Trichobothria } \\
\text { (1: absent; 2: present) }\end{array}$ & Reception of tactile signals & $1.27 \pm 0.04^{\mathrm{b}}$ & $1.43 \pm 0.03^{\mathrm{a}}$ & *** & $1.44 \pm 0.09^{\mathrm{ab}}$ & $1.41 \pm 0.04^{\mathrm{a}}$ & $1.34 \pm 0.05^{\mathrm{ab}}$ & $1.23 \pm 0.03^{\mathrm{b}}$ & $*$ \\
\hline $\begin{array}{l}\text { Anal spines } \\
\text { (1: absent; 2: present) }\end{array}$ & Mechanical defense against predation & $1.20 \pm 0.04$ & $1.12+0.02$ & NS & $1.18 \pm 0.07^{\mathrm{ab}}$ & $1.12 \pm 0.03^{b}$ & $1.12 \pm 0.03^{\mathrm{ab}}$ & $1.22 \pm 0.03^{\mathrm{a}}$ & $* *$ \\
\hline
\end{tabular}


Table 3. Mean values ( \pm SE) of trait diversities and multi-trait functional diversity (Rao's quadratic entropy) according to primary (spoil tip versus environment) and secondary (successional stage) environmental factors. Comparisons among groups were performed for each factor ('terril' effect and successional effect) by Kruskal-Wallis rank tests (NS = not significant, $* \mathrm{P}<0.05,{ }^{* *} \mathrm{P}<0.01,{ }^{* * *} \mathrm{P}<0.001,{ }^{* * * *} \mathrm{P}<0.0001$ ) followed by Dunn tests (different letters indicate significant differences among modalities after Bonferroni adjustment for multiple comparisons).

\begin{tabular}{|c|c|c|c|c|c|c|c|c|}
\hline & $\begin{array}{l}\text { Spoil tip } \\
(n=37)\end{array}$ & $\begin{array}{l}\text { Surrounding } \\
\text { environment } \\
(n=44)\end{array}$ & & $\begin{array}{l}\text { Bare } \\
(n=17) \\
\end{array}$ & $\begin{array}{l}\text { Herb } \\
(n=36)\end{array}$ & $\begin{array}{l}\text { Shrub } \\
(n=9)\end{array}$ & $\begin{array}{l}\text { Tree } \\
(n=22)\end{array}$ & \\
\hline Reproduction type & $0.175 \pm 0.014$ & $0.165 \pm 0.011$ & NS & $0.123 \pm 0.027$ & $0.156 \pm 0.013$ & $0.218 \pm 0.015$ & $0.202 \pm 0.010$ & NS \\
\hline Body length & $0.052 \pm 0.007^{b}$ & $0.081 \pm 0.007^{\mathrm{a}}$ & $* * *$ & $0.033 \pm 0.009^{b}$ & $0.093 \pm 0.008^{\mathrm{a}}$ & $0.061 \pm 0.015^{\mathrm{ab}}$ & $0.052 \pm 0.005^{b}$ & $* * * *$ \\
\hline Body shape & $0.030 \pm 0.004^{b}$ & $0.046 \pm 0.005^{a}$ & $*$ & $0.023 \pm 0.006$ & $0.047 \pm 0.006$ & $0.054 \pm 0.010$ & $0.030 \pm 0.004$ & NS \\
\hline Body colour & $0.152 \pm 0.010$ & $0.175 \pm 0.007$ & NS & $0.122 \pm 0.021^{b}$ & $0.163 \pm 0.008^{\mathrm{ab}}$ & $0.176 \pm 0.018^{\mathrm{ab}}$ & $0.189 \pm 0.009^{a}$ & $*$ \\
\hline Scales & $0.100 \pm 0.013^{b}$ & $0.162 \pm 0.010^{a}$ & $* *$ & $0.146 \pm 0.025$ & $0.147 \pm 0.014$ & $0.131 \pm 0.028$ & $0.106 \pm 0.013$ & NS \\
\hline Anter & $0.068 \pm 0.006$ & $0.070 \pm 0.005$ & NS & $0.042 \pm 0.009^{b}$ & $0.073 \pm 0.006^{\mathrm{a}}$ & $0.086 \pm 0.006^{a}$ & $0.074 \pm 0.005^{\mathrm{a}}$ & $* * *$ \\
\hline Leg length & $0.162 \pm 0.013$ & $0.153 \pm 0.011$ & NS & $0.119 \pm 0.025$ & $0.145 \pm 0.011$ & $0.175 \pm 0.025$ & $0.193 \pm 0.013$ & NS \\
\hline Furcula length & $0.107 \pm 0.011$ & $0.103 \pm 0.008$ & NS & $0.097 \pm 0.023^{\mathrm{ab}}$ & $0.084 \pm 0.008^{b}$ & $0.124 \pm 0.020^{\mathrm{ab}}$ & $0.136 \pm 0.011^{a}$ & $* *$ \\
\hline Eye number & $0.087 \pm 0.008^{b}$ & $0.112 \pm 0.007^{a}$ & $*$ & $0.075 \pm 0.014$ & $0.110 \pm 0.008$ & $0.104 \pm 0.019$ & $0.100 \pm 0.008$ & NS \\
\hline Pseu & $0.088 \pm 0.012$ & $0.082 \pm 0.009$ & NS & $0.081 \pm 0.020^{\mathrm{ab}}$ & $0.062 \pm 0.010^{b}$ & $0.071 \pm 0.015^{a b}$ & $0.128 \pm 0.014^{a}$ & $* *$ \\
\hline Post-antennal organ & $0.087 \pm 0.007$ & $0.097 \pm 0.005$ & NS & $0.085 \pm 0.016$ & $0.089 \pm 0.005$ & $0.097 \pm 0.011$ & $0.101 \pm 0.008$ & NS \\
\hline Trichobothria & $0.141 \pm 0.012^{b}$ & $0.207 \pm 0.008^{a}$ & $* * * *$ & $0.148 \pm 0.023$ & $0.192 \pm 0.011$ & $0.206 \pm 0.018$ & $0.160 \pm 0.014$ & NS \\
\hline Anal spines & $0.112 \pm 0.013$ & $0.096 \pm 0.010$ & NS & $0.082 \pm 0.020^{b}$ & $0.082 \pm 0.011^{b}$ & $0.097 \pm 0.021^{\mathrm{ab}}$ & $0.152 \pm 0.014^{a}$ & $* *$ \\
\hline Functional diversity & $1.36 \pm 0.08$ & $1.55 \pm 0.05$ & NS & $1.18 \pm 0.17$ & $1.44 \pm 0.06$ & $1.60 \pm 0.15$ & $1.62 \pm 0.08$ & NS \\
\hline
\end{tabular}


Table 4. Simple and partial redundancy analyses (RDA) used to ask some questions about site effect (11 sites), 'terril' effect (2 types: spoil tip, environment), plant successional effect (4 types: bare, herb, shrub, tree), surrounding land use effect (3 types: woodland, agriculture, urban) and soil physicochemistry ( 9 variables) on collembolan species presence/absence, Community Weighted Mean (CWM) trait values, and on trait diversity (Rao's quadratic entropy). ${ }^{*}=\mathrm{P}<0.05 ;{ }^{* *}=\mathrm{P}<0.01 ;{ }^{* * *}=\mathrm{P}<0.001 ;{ }^{* * * *}=$ $\mathrm{P}<0.0001 ; \mathrm{NS}=$ not significant. Yes $=$ included in the model as active factor; $\mathrm{No}=$ not included in the model; Fixed $=$ included in the model as a confounding factor (effects discarded).

\begin{tabular}{|c|c|c|c|c|c|c|c|c|}
\hline Number & Site effect & Terril effect & Successional effect & Land use effect & Soil effect & $\begin{array}{l}\text { Species } \\
\text { (\% explained) }\end{array}$ & $\begin{array}{l}\text { Traits (CWM) } \\
\text { (\% explained) }\end{array}$ & $\begin{array}{l}\text { Trait diversity } \\
\text { (\% explained) }\end{array}$ \\
\hline 1 & Yes & Yes & Yes & Yes & Yes & $39.0 * * * *$ & $40.8 * *$ & $42.8 * * * *$ \\
\hline 2 & Fixed & Yes & Yes & Yes & Yes & $24.8 * * * *$ & $29.2 * *$ & $16.2 * *$ \\
\hline 3 & Yes & Fixed & Fixed & Fixed & Fixed & $16.0 * * * *$ & $13.6 \mathrm{NS}$ & $16.2 * *$ \\
\hline 4 & Yes & No & No & No & No & $19.0 * * * *$ & 16.4 NS & $17.8 *$ \\
\hline 5 & Yes & Fixed & Fixed & No & Fixed & $19.4 * * * *$ & $16.0 \mathrm{NS}$ & $18.7^{*}$ \\
\hline 6 & No & Fixed & Fixed & Yes & Fixed & $4.1 * * * *$ & $2.7 \mathrm{NS}$ & $3.0 \mathrm{NS}$ \\
\hline 7 & Fixed & Yes & Fixed & Fixed & No & $3.2 * * * *$ & $5.4^{* *}$ & $2.6 \mathrm{NS}$ \\
\hline 8 & Fixed & Yes & Fixed & Fixed & Fixed & $2.5^{* * * *}$ & $1.8 \mathrm{NS}$ & $3.4^{*}$ \\
\hline 9 & Fixed & Fixed & Yes & Fixed & No & $9.0 * * * *$ & $10.2 * *$ & $14.0 * *$ \\
\hline 10 & Fixed & Fixed & Yes & Fixed & Fixed & $8.6^{* * * *}$ & $9.0 *$ & $13.6^{* * * *}$ \\
\hline 11 & Fixed & Fixed & Fixed & Fixed & Yes & 14.2 NS & $16.5 *$ & $16.6 *$ \\
\hline
\end{tabular}

